\title{
An Overview of Biomembrane Functions in Plant Responses to High-Temperature Stress
}

\author{
Yue Niu* and Yun Xiang* \\ MOE Key Laboratory of Cell Activities and Stress Adaptations, School of Life Sciences, Lanzhou University, Lanzhou, China
}

\section{OPEN ACCESS}

Edited by:

Eric Ruelland,

Centre National de la Recherche

Scientifique (CNRS), France

Reviewed by:

Ildikó Karsai,

Centre for Agricultural

Research (MTA), Hungary

Marina Gavilanes-Ruiz,

Universidad Nacional Autónoma

de México, Mexico

Pavel Pospísil,

Palacký University Olomouc, Czechia

${ }^{*}$ Correspondence:

Yue Niu

niuy@/zu.edu.cn

Yun Xiang

xiangy@/zu.edu.cn

Specialty section:

This article was submitted to

Plant Abiotic Stress,

a section of the journal

Frontiers in Plant Science

Received: 21 February 2018 Accepted: 08 June 2018

Published: 03 July 2018

Citation:

Niu Y and Xiang Y (2018) An Overview of Biomembrane Functions in Plant

Responses to High-Temperature Stress. Front. Plant Sci. 9:915. doi: 10.3389/fpls.2018.00915
Biological membranes are highly ordered structures consisting of mosaics of lipids and proteins. Elevated temperatures can directly and effectively change the properties of these membranes, including their fluidity and permeability, through a holistic effect that involves changes in the lipid composition and/or interactions between lipids and specific membrane proteins. Ultimately, high temperatures can alter microdomain remodeling and instantaneously relay ambient cues to downstream signaling pathways. Thus, dynamic membrane regulation not only helps cells perceive temperature changes but also participates in intracellular responses and determines a cell's fate. Moreover, due to the specific distribution of extra- and endomembrane elements, the plasma membrane (PM) and membranous organelles are individually responsible for distinct developmental events during plant adaptation to heat stress. This review describes recent studies that focused on the roles of various components that can alter the physical state of the plasma and thylakoid membranes as well as the crucial signaling pathways initiated through the membrane system, encompassing both endomembranes and membranous organelles in the context of heat stress responses.

Keywords: high temperature, plasma membrane, ER unfolded protein response, thylakoid membrane, heat-inducible pathway, membrane stress responses

\section{INTRODUCTION}

The Fifth Assessment Report of the IPCC (Intergovernmental Panel on Climate Change [IPCC], 2014a) showed that the increase in the global average surface temperature from 1880 to 2012 reached $0.85^{\circ} \mathrm{C}$, and the last three decades in particular were persistently warmer than any preceding decades. Moreover, the report predicted that the extreme annual daily maximum temperature would be elevated by approximately $1-3^{\circ} \mathrm{C}$ by the mid-21st century (Meehl and Tebaldi, 2004; Intergovernmental Panel on Climate Change [IPCC], 2014a). Although warming has been observed to benefit crop production in some highlatitude regions, the increasing threat of climate change has had negative impacts on crop yields over a wide range of areas, and the detrimental effects are expected to be aggravated in the next century (Intergovernmental Panel on Climate Change [IPCC], 2014b). In addition, secondary disasters that accompany high temperatures, such as drought and soil salinization, could trigger dramatic crop loss worldwide and even lead to global food shortages in the future. In fact, regardless of the climatological extremes, plants, being sessile, are inevitably exposed to a wide range of temperature stresses, including daily and/or seasonal temperature fluctuations that may reach dozens of degrees. Each plant species naturally exhibits its own optimal temperature range for growth and reproduction, and thus, extreme 
variations can rapidly exert a thermodynamic influence on the intracellular macromolecules (nucleic acids and proteins) and substructures of plant cells (Ruelland and Zachowski, 2010). For instance, a temperature of $5^{\circ} \mathrm{C}$ above optimal growing conditions can induce a series of changes in the organization of cell compartments, including the organelles and cytoskeleton, as well as the membrane microdomains necessary for plant survival at high temperatures (Weis and Berry, 1988; Guy, 1999; Bita and Gerats, 2013). Plants have evolved different adaptation mechanisms to withstand adverse conditions for optimal growth, the most common of which involve the activation of stress-induced gene expression related to the homeostatic adjustment of plant metabolism and development (Iba, 2002; Shinozaki et al., 2015). Therefore, breeding efforts focused on the transformation of these genes as supported by genetic approaches have been employed to efficiently improve plant adaptability to extreme temperatures (Grover et al., 2000; Sharkey, 2000). In particular, heat shock transcription factors and heat shock proteins (HSFs/HSPs) have been demonstrated to constitute a master regulatory pathway involved in the response to heat stress based on half a century of research, and some of these genes have since been applied in sustainable agriculture (Ritossa, 1962; Scharf et al., 2012). Nevertheless, in considering the mechanisms underlying the high-temperature stress response, one should not ignore how plants first quickly perceive and translate the stress into intracellular response signaling. In this respect, cell membranes, which constitute the barrier to the external environment and separate the cytosol into several microcompartments, are well suited for sensing stress and providing a "crosstalk" interface. Subtle alterations in lipids may affect various properties of the membrane, including its fluidity, thickness, permeability, and packing, and thus affect the clustering of important membrane proteins, which are sensitive to ambient conditions (Escribá et al., 2008). However, unlike in animal cells, membrane structures in plant cells possessing a cell wall may display an enormous and specific variety of components and functions (Malinsky et al., 2013). Combined with the diversity of plant responses to adverse environments, this complexity is such that the majority of the underlying thermotolerance mechanisms in plants remain unclear. The various challenges remaining in this field will be addressed in the following open questions.

In this review, we provide an overview of the currently known factors and/or mechanisms that can affect the states and properties of the plasma membrane (PM) and thylakoid membrane as well as the endoplasmic reticulum system (ER) in responses to and in tolerance of hightemperature stress in land plants (largely in reference to Arabidopsis thaliana). Some critical perspectives on the roles of membranes in these processes will also be presented, and we will discuss membrane-stress responses under heat stress within different plant taxa, including several psychrophiles, mesophiles, and thermophiles in the plant kingdom (as classified by Levitt, 1980; Zrobek-Sokolnik, 2012; Table 1).

\section{THE PM ACTS AS BOTH THERMOMETER AND THERMOSTAT TO PERCEIVE AND REACT TO HIGH TEMPERATURES}

\section{PM Composition and Microdomain}

Membranes serve as a selectively permeable barrier, and they are primarily composed of proteins and lipids in moving mosaics. Lipids with a polar head group and diverse types of long hydrophobic tails spontaneously form two leaflets in aqueous environments due to their amphipathic properties. Lipid species can be divided into three primary classes by chemical structure, namely, glycerolipids, sphingolipids and sterols (Enrique Gomez et al., 2017). Among the abundant glycerolipids, phospholipids predominantly occur in the PM and mitochondrial envelope, while galactolipids primarily constitute the thylakoid membrane (Dubots et al., 2012). Phospholipids contain two fatty acyl chains and a variable polar head group assembled to the glycerol backbone. Although phospholipids are usually sorted by their polar head groups, the fatty acid moieties greatly control their physicochemical properties (Escribá et al., 2008). The number and position of C-C bonds within hydrophobic acyl tails and the length of the carbon chains are thought to be key factors in determining the membrane fluidity (Fujimoto and Parmryd, 2017). Moreover, the lipid composition of each leaflet reflects another membrane property (asymmetry). Lipids are selectively embedded in membrane bilayers; phosphatidylcholine (PC), glycolipids and sphingomyelin are predominantly enriched on the exoplasmic face of the PM and the lumenal side of internal organelles, while phosphatidylserine (PS), phosphatidylethanolamine (PE), and phosphatidylinositol (PI) are primarily found on the cytoplasmic side; cholesterol shows preferential accumulation on the exoplasmic leaflet, although it can move freely between the two leaflets (Lenoir et al., 2007; Andersen et al., 2016). Additionally, some minor phospholipids, such as phosphatidic acid (PA), phosphatidylinositol-4-monophosphate (PIP) and phosphatidylinositol-4,5-biphosphate $\left(\mathrm{PIP}_{2}\right)$, are also enriched on the cytoplasmic leaflet (Gascard et al., 1991).

The fluid mosaic hypothesis proposed by Singer and Nicolson (1972) indicated that lipids formed a discontinuous, fluid bilayer in which proteins were embedded via specific interactions with lipids (). Today, evidence regarding the structure and function of membranes inspires us to consider the biomembrane as a more complex and exquisite device (Vereb et al., 2003; Cacas et al., 2012; Konrad and Ott, 2015). Different regions of membranes with defined lipids and clusters of proteins are not always equal, forming discrete platforms with varying sizes and traits in the plane of the membrane (which are denominated as membrane microdomains) (Karnovsky et al., 1982; Thompson and Tillack, 1985; Simons and Ikonen, 1997; Simons and Toomre, 2000; Lillemeier et al., 2006; Figure 1). Historically, lipid rafts enriched in sphingolipids, sterols and glycosylphosphatidylinositol (GPI)-anchored proteins were thought to be equivalent to membrane microdomains or detergent-insoluble membranes 
TABLE 1 | Membrane-stress responses under heat stress within different plant taxa.

\begin{tabular}{|c|c|c|c|c|c|}
\hline Species & Distribution & $\begin{array}{l}\text { Optimum } \\
\text { temperature }\end{array}$ & Heat stress & $\begin{array}{l}\text { Membrane-associated tolerance } \\
\text { mechanisms }\end{array}$ & Reference \\
\hline $\begin{array}{l}\text { Deschampsia } \\
\text { antarctica } \\
\text { Colobanthus quitensis }\end{array}$ & $\begin{array}{l}\text { The west coast of } \\
\text { Antarctica }\end{array}$ & $\begin{array}{l}10^{\circ} \mathrm{C} \\
12-14^{\circ} \mathrm{C}\end{array}$ & $\begin{array}{l}>22^{\circ} \mathrm{C} \\
>26^{\circ} \mathrm{C}\end{array}$ & $\begin{array}{l}\text { The rates of whole-canopy net photosynthesis } \\
(\mathrm{Pn}) \text { are sharply decreased under high } \\
\text { temperature; can still keep } 30 \% \text { of the maximal } \\
\text { rate of } \mathrm{Pn} \text { when temperature close to } 0^{\circ} \mathrm{C} \text {. }\end{array}$ & Xiong et al., 2000 \\
\hline $\begin{array}{l}\text { Green alga } \\
\text { (Chlamydomonas } \\
\text { reinhardtii) }\end{array}$ & World-wide (soil) & $24^{\circ} \mathrm{C}$ & $>37^{\circ} \mathrm{C}$ & $\begin{array}{l}\text { Rapidly increasing glycerophosphoglycerol (GPG, } \\
\text { splitted from PG by PA/lipid acyl hydrolase); } \\
\text { Increasing in saturated FAs and TAGs with } \\
\text { polyunsaturated FAs accumulated within lipid } \\
\text { bodies; } \\
\text { Rapid arrest of } \mathrm{CO}_{2} \text { fixation for NADPH and ATP } \\
\text { in de novo synthesis of saturated FAs; } \\
\text { LHCll uncoupling and reactivating } \mathrm{CO}_{2} \text { fixation in } \\
\text { long term HS; } \\
\text { Decrease of PG and SQDG may restrain } \\
\text { photosystem assembly; } \\
\text { Chaperones are rapidly accumulated in cytosol, } \\
\text { plastid, mitochondrion and ER. }\end{array}$ & $\begin{array}{l}\text { Lamosa et al., 2000; } \\
\text { Pröschold et al., 2005; } \\
\text { Merchant et al., 2006; } \\
\text { Hemme et al., 2014; } \\
\text { Schroda et al., } 2015\end{array}$ \\
\hline Rice (Oryza sativa) & $\begin{array}{l}\text { Tropical and } \\
\text { subtropical regions } \\
\text { of South and } \\
\text { Southeast Asia } \\
\text { (China, Japan, } \\
\text { Philippines etc.) }\end{array}$ & $\begin{array}{l}\text { Day/night } \\
\text { temperature } \\
30^{\circ} \mathrm{C} / 25^{\circ} \mathrm{C}\end{array}$ & $\begin{array}{l}>35^{\circ} \mathrm{C} \\
>40^{\circ} \mathrm{C} \\
\text { (sufficient } \\
\text { irrigation water) }\end{array}$ & $\begin{array}{l}\text { The homologs involved in heat stress response in } \\
\text { Arabidopsis mostly can be identified in rice. } \\
\text { e.g., Some Rice RBOHs (NADPH oxidases, } \\
\text { OsNoxs) are indicated in heat-induced ROS } \\
\text { signaling; } \\
\text { The oscillation of } \mathrm{Ca}^{2}+\text { signature can induce the } \\
\text { rice CaM1 -1 isoform to transmit the HS signal } \\
\text { to sHSPC/N; } \\
\text { Rice PEP-associated protein (WLP2) can protect } \\
\text { chloroplast development under heat stress via } \\
\text { maintaining the redox balance and regulating the } \\
\text { expression of PEP-encoded genes. }\end{array}$ & $\begin{array}{l}\text { Wu and Jinn, 2012; } \\
\text { Wang et al., 2013; } \\
\text { Jagadish et al., 2015; } \\
\text { Lv et al., } 2017\end{array}$ \\
\hline $\begin{array}{l}\text { New Rice for Africa line } \\
\text { (NERICAs L-44 (NL-44)) } \\
\text { New Rice for Africa line } \\
\text { (NERICAs } 22 \text { (N22)) }\end{array}$ & $\begin{array}{l}\text { Field experiment in } \\
\text { India, Philippines }\end{array}$ & $28^{\circ} \mathrm{C}$ & $>38^{\circ} \mathrm{C}$ & $\begin{array}{l}\text { The cultivars possess high photosynthesis, } \\
\text { scavenging enzyme activities and membrane } \\
\text { stability as well as low ROS products. }\end{array}$ & Bahuguna et al., 2015 \\
\hline $\begin{array}{l}\text { Wheat (Triticum } \\
\text { aestivum) }\end{array}$ & $\begin{array}{l}\text { Widely cultivated in } \\
\text { temperate regions }\end{array}$ & $18-25^{\circ} \mathrm{C}$ & $>32^{\circ} \mathrm{C}$ & $\begin{array}{l}\text { An increased ratio of DGDG to MGDG, especially } \\
\text { high levels of saturation of DGDG can enhance } \\
\text { the thermostability of thylakoid membrane; } \\
\text { Low expression of electrolyte leakage from leaf } \\
\text { cells can maintain membrane thermostability; } \\
\text { Several genes may simultaneously control the } \\
\text { membrane stability under heat stress. }\end{array}$ & $\begin{array}{l}\text { Mullarkey and Jones, } \\
\text { 2000; Cossani and } \\
\text { Reynolds, 2012; } \\
\text { Dhanda and Munjal, } \\
2012\end{array}$ \\
\hline Arabis paniculata & Alpine region & $22^{\circ} \mathrm{C}$ & $>38^{\circ} \mathrm{C}$ & $\begin{array}{l}\text { The degree of lipid unsaturation is rapidly } \\
\text { decreased; and higher level of HSPs is induced } \\
\text { and maintained. }\end{array}$ & Tang et al., 2016 \\
\hline $\begin{array}{l}\text { Dichanthelium } \\
\text { lanuginosum }\end{array}$ & $\begin{array}{l}\text { Geothermally } \\
\text { heated } \\
\text { environments } \\
\text { (North America) }\end{array}$ & $35^{\circ}-41^{\circ} \mathrm{C}$ & $>45^{\circ} \mathrm{C}$ & $\begin{array}{l}\text { The plant has higher shoot fresh water under high } \\
\text { temperature; and the cells express low molecular } \\
\text { weight HSPs and thermostable enzymes. }\end{array}$ & Stout et al., 1997 \\
\hline
\end{tabular}

(treated with $1 \%$ Triton X-100 at $4^{\circ} \mathrm{C}$; Brown and Rose, 1992; Cacas et al., 2012; Malinsky et al., 2013). Over the past decade, this idea has come to be considered controversial, if all of the above concepts reflect the authentic membrane substructure (Malinsky et al., 2013). With the development of experimental approaches, the microdomains of membranes can now be distinguished at multiple scales (reviewed by Konrad and Ott, 2015). Nanoscale domains based on lipid rafts $(2-100 \mathrm{~nm})$ are incorporated into larger microdomains (e.g., raft platforms) via the interactions between specific lipids and proteins; both cytoskeleton and cell wall components prop up the largest units, which are denominated as the membrane compartments (40-300 nm), depending on the cytoskeletal and cell wall restriction of the lateral diffusion of membrane proteins (Kusumi et al., 2005, 2011, 2012; Jacobson et al., 2007; Martinière et al., 2012). In contrast to lipid rafts with a highly dynamic nature in mammalian cells, special lateral membrane compartments in plant cells are more stable (Cacas et al., 2012; Malinsky et al., 2013). Substantial evidence supports the notion that the microdomain acts as a harbor in which cellular signaling is clustered by the interactions between membrane components (including previously isolated channels, receptors, other signaling complexes and specific 


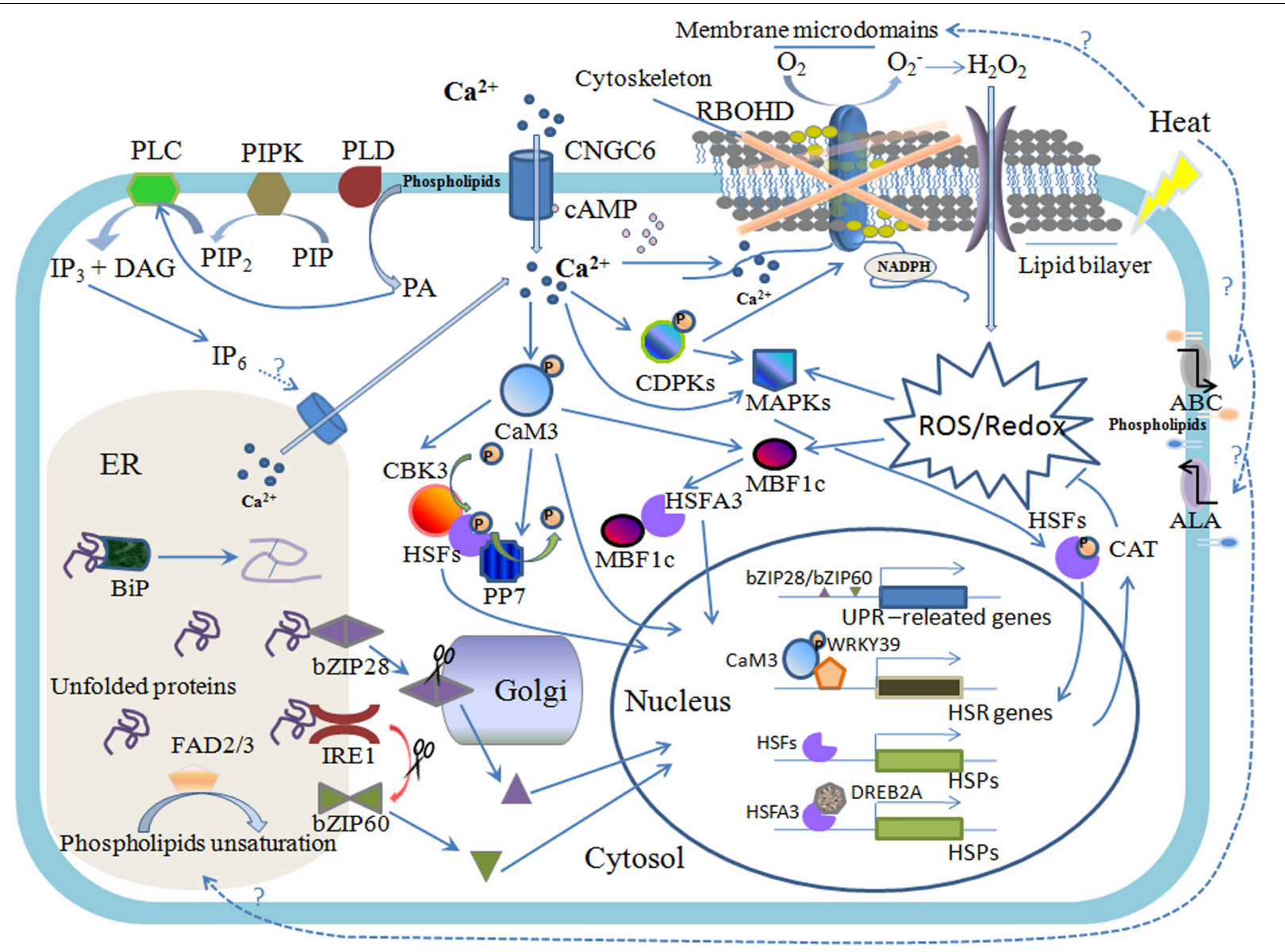

FIGURE 1 | Plasma membrane (PM) and ER are involved in the plant heat stress response. Heat stress alters the physical state of membranes and affects membrane proteins as well as the membrane structure; for example, membrane microdomains can be subtly changed, which induces the clustering of signaling proteins correspondingly to make adjustments. The PM-located RBOHD is embraced within and regulated by the special membrane region; the calcium-permeable channel CNGC6, which is activated by cyclic adenosine monophosphate (CAMP), primarily mediates the calcium influx; and lipid translocases ABC and ALA cope with structural lipid flipping and/or flopping, resulting in changes to the membrane stability. Membrane-associated PIPK, PLD, and PLC perceive changes in the states of membranes and trigger the lipid-signaling molecules $\mathrm{PIP}_{2}$, PA, and $\mathrm{IP}_{3}$, respectively, and when phosphorylated to $\mathrm{IP}_{6}$, $\mathrm{IP}_{3}$ can mediate the calcium release from the ER. The burst of cytosolic calcium can also activate the RBOHD, which induces a rapid increase in hydrogen peroxide $\left(\mathrm{H}_{2} \mathrm{O}_{2}\right)$ and triggers the ROS/redox signaling pathway, including MAPK-HSFs and MBF1c-HSFA3-DREB2A, during the heat stress response (HSR). MAPK-HSFs can regulate the expression of CAT, conversely controlling the level of ROS; the phosphorylation of calcium-dependent protein kinase (CDPK) also activates RBOHD. Calcium binding to CaM3 evokes CBK3/PP7 and the transcription factors of the HSR, such as HSFs and WRKY39. The heat sensors involved in the ER-UPR are comprised of bZIP28 (spliced in Golgi) and IRE1 (splicing bZIP60 mRNA), and ER-UPR also requires chaperone BiP binding to unfold protein for correct folding. The FAD2 and FAD3 in the ER are important components in the control of membrane fluidity during the HSR.

lipids) during many physiological processes, such as biotic and abiotic stress responses, membrane transport and polarized plant growth (Laude and Prior, 2004; Lingwood and Simons, 2010; Malinsky et al., 2013; Jarsch et al., 2014; Wang et al., 2018). An ROS-generating enzyme known as respiratory burst oxidase homolog $\mathrm{D}$ (RBOHD) has been suggested to localize to membrane microdomains (Lherminier et al., 2009; Hao et al., 2014; Figure 1) and could be activated by a heatinduced cytosolic calcium increase to immediately produce an oxidative burst (Suzuki et al., 2011). However, numerous microdomain-associated proteins remain to be elucidated in plants. Notably, increasing evidence from mammals has illustrated that several HSPs localize to PM rafts via interactions with specific lipids (reviewed by Escribá et al., 2008). These
HSPs include abundant HSP70, HSP90 and other small HSPs (e.g., HSP27), the functions of which have been suggested to include the recruitment of signaling proteins to the PM, the folding of membrane proteins, assisting polypeptides in translocation across the membrane bilayer, and rapidly remodeling and protecting the PM under cellular stresses (Arispe et al., 2002; Shah et al., 2002; Vega and De Maio, 2005; Vigh et al., 2005, 2007b). Although the mechanism controlling the interactions between HSPs and membrane lipids and proteins is less well known, it is speculated that the structure of lipid rafts is crucial for HSPs to perform their individual functions in cell responses (Escribá et al., 2008). Whether HSPs in plants exhibit similar behaviors at PM microdomains has not yet been explored. 


\section{Lipid Saturation and Desaturases}

Plants that survive under extreme temperatures must first maintain constant membrane fluidity and integrity, which requires dynamic changes in the membrane composition. Early studies have shown that the ratio of saturated and unsaturated fatty acids differs greatly between lipid species and tissues (Yabuuchi and O'Brien, 1968; Wood and Harlow, 1969). In addition, the saturated and monounsaturated fatty acid contents increase in response to elevated temperatures, while the proportion of polyunsaturated fatty acids can be increased by a sudden drop in temperature (Wallis and Browse, 2002; Penfield, 2008). Temperature is the most important contributing factor in regulating the unsaturation degree of fatty acid chains, and thus, it has a large impact on the properties of membrane bilayers (Ruelland and Zachowski, 2010; Furt et al., 2011). The numbers and sites of double bonds within fatty acid chains are modified by desaturases via an oxygen-dependent reaction (Aguilar and de Mendoza, 2006). In plants, the fatty acid desaturase $(F A D)$ family, which plays an important role in adaptation to high-temperature stress, has been studied extensively. Among the eight members of the Arabidopsis FAD family (FAD1 to FAD8), FAD2 and FAD3 are located in the ER membrane, while the others are plasmidspecific desaturases (Browse and Somerville, 1991; Heinz, 1993; Figure 1). Although the synthesis and unsaturation of the major lipids are performed in the chloroplasts or ER in higher plants, acyl chain modifications of lipids embedded in the PM rely on regulation by various desaturases and on lipid transfer (Wallis and Browse, 2002; Singer et al., 2016). Ambient stresses, such as temperature fluctuations, are perceived by the PM and/or membranous organelles and can affect FAD activities at both the transcriptional and post-transcriptional levels, thereby altering the membrane fluidity (Singer et al., 2016). Recently, increasing evidence has shown that FAD2 and FAD3 are unstable and less enriched at elevated temperatures (Dyer and Mullen, 2001; Sánchez-García et al., 2004; Tang et al., 2005; O’Quin et al., 2010; Khuu et al., 2011). The seedlings of the fad 2 mutant are unable to elongate their stems at $12^{\circ} \mathrm{C}$ and die at $6^{\circ} \mathrm{C}$ (Miquel et al., 1993); similarly, the lethal temperature for fad1 is $2^{\circ} \mathrm{C}(\mathrm{Wu}$ et al., 1997). Interestingly, the dwarf fad 2 plant has been found to exhibit enhanced reactive oxygen species (ROS) and salicylic acid (SA) signaling, which are considered to regulate the heat stress response (Kachroo et al., 2004; Larkindale et al., 2005). Additionally, other fad mutants, such as fad5, show higher growth rates depending on the thermal conditions. FAD3, FAD7, and FAD8 have all been demonstrated to confer high-temperature instability (Horiguchi et al., 2000; Matsuda et al., 2005), and three transgenic lines have exhibited higher levels of trienoic fatty acids in response to extreme temperatures (Kodama et al., 1995; Zhang et al., 2005; Penfield, 2008). In fact, the varying amounts of unsaturated fatty acids incorporated into the major glycerolipids in fad mutants alter the composition and properties of their membranes, which may be the reason why their cells can sense and react to high temperatures (Wallis and Browse, 2002). Confusingly, however, the mechanism through which FADs rapidly react to sudden temperature fluctuations and upstream factors with temperature sensitivity to regulate the activities of FADs remains unclear in plants.

\section{Membrane Asymmetry and Lipid Translocases}

It is not only the chemical constitution of lipid membrane bilayers that is closely associated with the temperature; the multiple types of molecular motion by lipids (including rotation around their own axes, lateral diffusion within a monolayer and flip-flopping between the two monolayers) involved in the physical properties of the membrane are also highly temperature dependent (Ruelland and Zachowski, 2010). The transbilayer translocation of lipids is crucial for maintaining lipid asymmetry, which is necessary for membrane stability and the production of transport vesicles; translocation is also related to the demands of cell growth as well as cellular responses to physiological stresses (Pomorski and Menon, 2016). For instance, PS acts as a common type of phospholipid that is inserted in the membranes, and the flipping of the PS under stress is considered to be an important "eat-me" signal for macrophages in eukaryotes (Segawa et al., 2011, 2014). In general, the asymmetrical distribution of lipids can be achieved through the actions of three protein families, scramblases, $\mathrm{ABC}$ transporters and $\mathrm{P}_{4}$-ATPases, which are found in plants and other organisms. The first group of proteins catalyzes the ATP-free bidirectional movement of lipids, whereas most $\mathrm{ABC}$ transporters shift lipids from the cytoplasmic to the exoplasmic leaflet (flopping), and $\mathrm{P}_{4}$-ATPases do just the opposite (flipping) (Pomorski and Menon, 2016; Figure 1). The implications of scramblases in abiotic stress responses in the plant kingdom remain unclear, but there are a number of reports on the involvement of the other two types of floppase/flippase in responding to environmental challenges, including extreme temperatures. ABC transporters in A. thaliana belong to a large protein family with 129 members. Among these transporters, a previous study showed that reducing the functions of plasmid-specific ABC proteins TGD1, 2, 3, and 4 can effectively suppress the low-temperature-induced phenotype of the vte 2 mutant (Song et al., 2010). Earlier research indicated that the transcription of a homolog (TUR2) of the yeast ABC transporter gene PDR5 was induced by low temperatures in Spirodela polyrrhiza (Smart and Fleming, 1996). Li et al. (2011) found that the expression of $\mathrm{ABC} 1$ was specifically induced under a combination of saline and heat shock stresses in Suaeda salsa. Moreover, a subsequent report suggested that similar to other abiotic-stress-related genes, ABC transporters were abundantly enriched during cold acclimation in the grapevine Vitis amurensis (Wu et al., 2014). Likewise, $12 \mathrm{P}_{4}$-ATPases in the Arabidopsis genome designated ALA1 to ALA12 were shown to perform inward lipid translocation (Axelsen and Palmgren, 1998), and the evidence obtained to date demonstrates that the functions of the proteins in this group are all affected to varying degrees by temperature fluctuations. For instance, ALA1 was shown to play a crucial role in chilling tolerance (Gomès et al., 2000), while ALA3 regulates vegetative and reproductive growth in a temperaturedependent manner (McDowell et al., 2013). ALA6 and ALA7 determine the fitness of pollen by regulating adaptations to 
daily temperature swings (McDowell et al., 2015), and ALA6 has been verified to directly participate in thermotolerance (Niu et al., 2017). In addition, a recent study suggested that ALA10 contributed to regulating the activities of FAD2/FAD3 to control galactolipid synthesis in leaf development, and this positive regulation is susceptible to chilling stress (Botella et al., 2016). Nevertheless, solid evidence for the involvement of lipid translocation in temperature sensing has yet to be obtained.

\section{Heat-Induced PM Stress Perception}

Temperature is a physical cue, and it directly alters the fluidity of biomembranes and the remodeling of membrane microdomains. This may have comprehensive effects not only on the membrane composition but also on specific interactions between lipids and proteins such as ion channels and kinases, subsequently altering the conformation and function of proteins and triggering particular signal transduction pathways (Plieth, 1999; Vigh et al., 2007a; Figure 1). Cells remodel and reestablish membrane fluidity to cope with a change in the ambient temperature via the real-time control of lipid saturation and fatty acid length (Schroda et al., 2015). Above all, subtle changes in membrane fluidity should be promptly perceived by PM sensors. Although studies have indicated that there are several ion channels that function as temperature sensors in animal cells, such as the transient receptor potential cation channel subfamily V (TRPV) and cyclic nucleotidegated channels (CNGCs; Ramot et al., 2008; Yao et al., 2011), the PM thermosensor in plants long remained unidentified until the existence of primary sensors for heat stress was revealed in the PM of Physcomitrella patens (Saidi et al., 2009, 2011). However, the membrane fluidizer benzyl alcohol can mimic the effects of high temperatures on the PM calcium-dependent heat shock response (HSR); conversely, the rigidifying agent dimethyl sulfoxide can decrease the heatactivated expression of HSPs (Saidi et al., 2005, 2009; Suri and Dhindsa, 2008), which also supports the conclusion that heat-mediated calcium channels are probably regulated by membrane fluidity (Saidi et al., 2009, 2010). Further evidence of the role of these calcium channels as "thermosensors" in plants is needed. In particular, it is poorly understood how these calcium channels perceive and distinguish among different types of high-temperature stress (e.g., basal heat shock, warm priming/acclimation before heat shock, gradual temperature increases, hot-day/cold-night, or short-term and long-term heat stress).

\section{Heat-Induced Second Messengers and Signal Cascades}

One of the earliest identified plant responses to elevated temperatures was a specific transient $\mathrm{Ca}^{2+}$ influx from the extracellular matrix to the cytoplasm (Gong et al., 1998; Liu et al., 2006). The effective suppression of the HSR pathway in higher plants by both calcium chelators and channel blockers suggested that an inward flux of $\mathrm{Ca}^{2+}$ and the ensuing signaling could play critical roles in the heat stress response (Braam, 1992; Larkindale and Knight, 2002; Li et al., 2004; Suri and Dhindsa,
2008). The presence of a calcium spike within seconds of thermal treatment in most model plants strongly indicates that heatsensitive calcium-permeable channels are present in the PM and can transiently open or close during the thermotolerance process (Gong et al., 1998; Liu et al., 2006; Saidi et al., 2009; Wu and Jinn, 2010). Over 40 putative calcium channels located in the PM in the A. thaliana genome are regarded as the candidate heat sensors (Ward et al., 2009). Gao et al. (2012) indicated that cyclic nucleotide-gated ion channel 6 (CNGC6) might mediate the heat-activated $\mathrm{Ca}^{2+}$ influx and the expression of HSPs in A. thaliana during plant adaptive responses to heat (Figure 1). Additionally, CNGC6 was also activated by cytosolic cyclic adenosine monophosphate (cAMP), the concentration of which could be rapidly increased within 2 min after heat shock. The binding of free $\mathrm{Ca}^{2+}$ ions to calmodulins (CaMs) has been demonstrated to trigger PM calcium signal cascades, which can activate the HSF and HSP networks (von Koskull-Döring et al., 2007). In A. thaliana, AtCaM3 is primarily involved in the activation of transcription factors comprising HSFs, multiprotein bridging factor 1c (MBF1c), WRKY DNA-binding domain superfamily protein (WRKY39) and dehydration-responsive element binding protein (DREB) (Li et al., 2010; Liu et al., 2011; Suzuki et al., 2011; Figure 1). MBF1c has been demonstrated to regulate the expression of over 30 heat-related transcripts, including HSFB2a and HSFB2b as well as DREB2A, which is upstream of HSFA3 (Schramm et al., 2008; Suzuki et al., 2011). WRKY39 facilitates the jasmonic acid and SA signaling pathways under heat stress (Li et al., 2010). With respect to the HSFs and the HSF-HSP signaling pathway, the numerous efforts aimed at understanding these proteins began as early as 1960s and 1970s and will therefore not be addressed in this review (see reviews from Baniwal et al., 2004; Kotak et al., 2007; von Koskull-Döring et al., 2007; Saidi et al., 2011). AtCaM3 binds to the Arabidopsis CaM-binding protein kinase 3 (AtCBK3) to promote the phosphorylation of HSFAla via the activation of a heat-induced transient $\mathrm{Ca}^{2+}$ increase (Liu et al., 2008; Saidi et al., 2011), while calmodulin-dependent phosphatase 7 (PP7) mediates the dephosphorylation of HSFA1a in a $\mathrm{Ca}^{2+}$-dependent manner (Liu et al., 2007a; Bokszczanin et al., 2013).

Hydrogen peroxide $\left(\mathrm{H}_{2} \mathrm{O}_{2}\right)$ is considered to be the other crucial second messenger when plants are exposed to elevated temperatures, because a rapid accumulation of $\mathrm{H}_{2} \mathrm{O}_{2}$ can occur within several minutes (Konigshofer et al., 2008). The PM-located protein $\mathrm{RBOHD}$ is involved in the generation of $\mathrm{H}_{2} \mathrm{O}_{2}$ and is directly activated by an increase in cytosolic calcium and/or the phosphorylation of a calcium-dependent protein kinase (CDPK; Suzuki et al., 2011; Figure 1). The downstream signal cascades of RBOHD also comprise certain HSFs, mitogen-activated protein kinases (MAPKs) and MBF1c, which are involved in HSR (Mittler et al., 2004, Miller et al., 2009; Suzuki et al., 2011; Figure 1). For example, HSFA4a might be a sensor of the $\mathrm{H}_{2} \mathrm{O}_{2}$ signaling, while HSFA5 serves as a repressor of this pathway (Miller and Mittler, 2006; Baniwal et al., 2007). MAPKs can affect the expression and activity of catalase (CAT) to control the ROS levels while conversely regulating the expression of $\mathrm{RBOHD}$ in various genera (Ortiz-Masia et al., 2008; Xing et al., 2008; Pitzschke and Hirt, 2009; Zong et al., 2009; Liu and He, 2016). 
In addition, studies have shown that more than 1000 lipids are engaged in stress-induced cell signaling, a number far exceeding that of structural lipids (Vigh et al., 2007a; van Meer et al., 2008). Lipids themselves appear to be versatile, acting not only as structural components but also as signaling mediators. One wellknown example is the obvious rapid increases in PA and $\mathrm{PIP}_{2}$ observed under heat stress, the synthesis of which are catalyzed by PM-localized phospholipase D (PLD) and phosphatidylinositol4-phosphate 5-kinase (PIPK), respectively (Mishkind et al., 2009; Figure 1). Heat-induced changes in membrane fluidity might activate phospholipases and kinases on the PM, including PLD and PIPK. Additionally, $\mathrm{PIP}_{2}$ is hydrolyzed by membranebound PLCs and releases diacylglycerol (DAG) and inositol 1,4,5-triphosphate $\left(\mathrm{IP}_{3}\right)$, which increases rapidly within $3 \mathrm{~min}$ after heat shock in Arabidopsis (Zheng et al., 2012). IP , which is generally considered a classic second messenger that is phosphorylated into $\mathrm{IP}_{6}$, is implicated in the regulation of intracellular calcium stores (Ren et al., 2017; Figure 1). However, an $\mathrm{IP}_{6}$ receptor has yet to be identified in plants. Furthermore, $\mathrm{PIP}_{2}$ itself also plays an important role in biotic and abiotic stresssignaling transduction that are related, for example, to membrane stability, the cytoskeletal order and the budding of secretory vesicles (Siddhanta and Shields, 1998; Di Paolo and De Camilli, 2006; Mishkind et al., 2009). PA is a structural lipid, and it acts as a key coordinator of the PLC signaling pathway in plants (Testerink and Munnik, 2005). Arabidopsis AtPLC3 and AtPLC9 are associated with the regulation of small HSP ( $s H S P$ ) expression during the thermotolerance process by the same mechanisms (Zheng et al., 2012; Ren et al., 2017).

\section{Cold-Induced PM Stress Signal Cascades}

A growth temperature that is higher or lower than the optimum range is defined as heat or cold stress. Although this concept is related to different plants, in general, cold-sensitive species can be harmed at temperatures below $15^{\circ} \mathrm{C}$, while cold-tolerant plants may survive at temperatures close to $5^{\circ} \mathrm{C}$ (Chen, 1994; Nievola et al., 2017). As temperature effects, the cold signaling responses involve similar stages as those observed in plants exposed to heat. For instance, the cold first has an influence on the membrane fluidity via fatty acid saturation. In contrast to heat stress, low temperatures cause changes in the physical state of the membrane bilayer from a fluid-crystalline phase to a solid-gel phase, accompanied by decreased permeability, which is referred to as the membrane rigidity (Buchanan et al., 2015). Incremental membrane rigidity can also alter the activities of some channels, kinases and G-protein-associated receptors on the PM and thus rapidly induce increases in intracellular calcium, PA, and ROS similar to those in heat-treated cells (Plieth et al., 1999; Ruelland et al., 2002; Gupta et al., 2011). However, differences between these two types of temperature stress arise in the subsequent signal cascades (Kaplan et al., 2004; McClung and Davis, 2010; Zhou et al., 2014). The increased PA, which can be produced by activated PLD under cold conditions, can trigger ROS production in cells and may be involved in the ABA-dependent responses under cold stress (Ruelland et al., 2002; Guo, 2011; Gupta et al., 2011). In addition, a $\mathrm{Ca}^{2+}$ signature can be decoded by many calcium sensors (Miura and Furumoto, 2013), among which the CaM-binding transcription activator (CAMTA3) has been shown to bind to the promoters of C-repeat-binding factors $(C B F 2 / D R E B 1 C)$ and induce their gene expression (Doherty et al., 2009). The MAPK cascades are also implicated in the up-regulation of $C B F / D R E B 1 s$ transcription factors during cold stress signaling, including that of MPK3, MPK4, and MPK6 in Arabidopsis (Smékalová et al., 2014). CBF-dependent cold-responsive (COR) gene expression is considered to be a central regulatory pathway in the cold stress response (Chinnusamy et al., 2007), which is regulated by ICEs (inducers of $C B F$ expression; Chinnusamy et al., 2003). The numbers and categories of COR genes are diverse; some of their products have been found to maintain cell membrane structures, activate ROS-scavenging enzymes, and promote the accumulation of osmolytes when plants are exposed to cold stress (Guy, 1990; Cook et al., 2004; Hannah et al., 2005; Maruyama et al., 2009). Interestingly, Fowler and Thomashow (2002) identified 130 CORs that were similarly induced by warm temperatures according to analyses in $C B F$-overexpressing plants. Furthermore, HSFC1 positively regulates $C O R$ gene expression independent of the CBF2 signaling pathway under freezing conditions (Park et al., 2015). Thus, the different types of temperature (heat or cold)-induced signal transduction share an affinity with each other in terms of both molecular components and signaling pathways, which may start at temperature-altered membrane fluidity and induce responsive gene expression to maintain cell integrity and function. Additionally, similar to studies on HSR, the specific plant sensors for the cold stress response and the mechanisms by which the sensors perceive cold signaling remain to be further elucidated (Miura and Furumoto, 2013).

\section{ROLES OF THE CHLOROPLAST AND MITOCHONDRION IN HEAT STRESS SENSING AND RESPONSES}

The chloroplast and mitochondrion are membranous organelles in which carbon metabolism and energy exchange occur. Due to the ROS [including $\mathrm{H}_{2} \mathrm{O}_{2}$, superoxide anions $\left(\mathrm{O}_{2}{ }^{\bullet-}\right)$, hydroxyl radicals $\left({ }^{\bullet} \mathrm{OH}\right)$, and singlet oxygen $\left.\left({ }^{1} \mathrm{O}_{2}\right)\right]$ that are produced in the electron transport chain and the accompanying metabolic energy distribution during photosynthesis and respiration, chloroplast and mitochondrion components are the major targets of oxidative damage in plants, especially in the presence of other environmental stresses, such as high temperatures (Asada, 2006; Suzuki et al., 2012; Pospíšil and Prasad, 2014). Moreover, because both the chloroplast and mitochondrion are semiautonomous organelles regulated by the nucleus, the communication of organelle stresses to the nucleus and the modulation of the expression of stressrelated genes, which are defined as retrograde signaling pathways, are considered to be extremely significant during physiological challenges, including heat stress (Sun and Guo, 2016; Figure 2). 


\section{Chloroplasts}

In chloroplasts, the photosynthetic apparatus primarily consists of the thylakoid membrane; all the components related to photon capture, electron transfer and energy exchange are found in different compartments of the thylakoid, and its lipid composition and physical state therefore appear to be particularly important for the photosynthetic system. Unlike the PM, the thylakoid membrane is composed of highly unsaturated glyceroglycolipids containing considerable amounts of monogalactosyldiacylglycerol (MGDG) and digalactosyldiacylglycerol (DGDG) as well as small amounts of phosphatidylglycerol (PG) and sulfoquinovosyldiacylglycerol (SQDG) (Dorne et al., 1990; Somerville et al., 2000; Pospísil and Yamamoto, 2017). Hence, polyunsaturated fatty acids unavoidably become a site of attack by lipid peroxyl radicals under heat stress if the fatty acid moiety is near the $\mathrm{Q}_{B}$ site on the PSII electron acceptor side, suggesting that the fluidity of the thylakoid membrane is important for PSII function (Triantaphylides et al., 2008; Yamashita et al., 2008;
Triantaphylides and Havaux, 2009; Figure 2). Moreover, both ${ }^{1} \mathrm{O}_{2}$ formation on the electron acceptor side and ${ }^{\bullet} \mathrm{OH}$ production on the electron donor side result from the inactivation of PSII electron transport when plants are exposed to heat stress (Yadav and Pospísil, 2012). For instance, high temperatures efficiently shift the midpoint redox potential of $\mathrm{Q}_{A} / \mathrm{Q}_{A}{ }^{-}$, which leads to the suppression of electron transfer from $\mathrm{Q}_{A}$ to $\mathrm{Q}_{B}$ on the electron acceptor side of PSII (Pospišil and Tyystiärvi, 1999). In the green alga Chlamydomonas reinhardtii, ${ }^{1} \mathrm{O}_{2}$ formation as initiated by heat-induced lipid peroxidation, in which lipoxygenase plays the primary role, has been demonstrated (Prasad et al., 2016). Lipid peroxidation products also have a pernicious effect on PSII proteins via oxidative modification, protein cleavage and irreversible protein aggregation (Chan et al., 2012; Yamamoto et al., 2014). Studies have shown that the reaction center binding protein D1 can be cleaved in spinach thylakoid membranes under heat stress (Yoshioka et al., 2006) and that lipid peroxidation occurs in spinach thylakoids (Yamamoto et al., 2008; Yamashita et al., 2008), and ${ }^{1} \mathrm{O}_{2}$ is subsequently
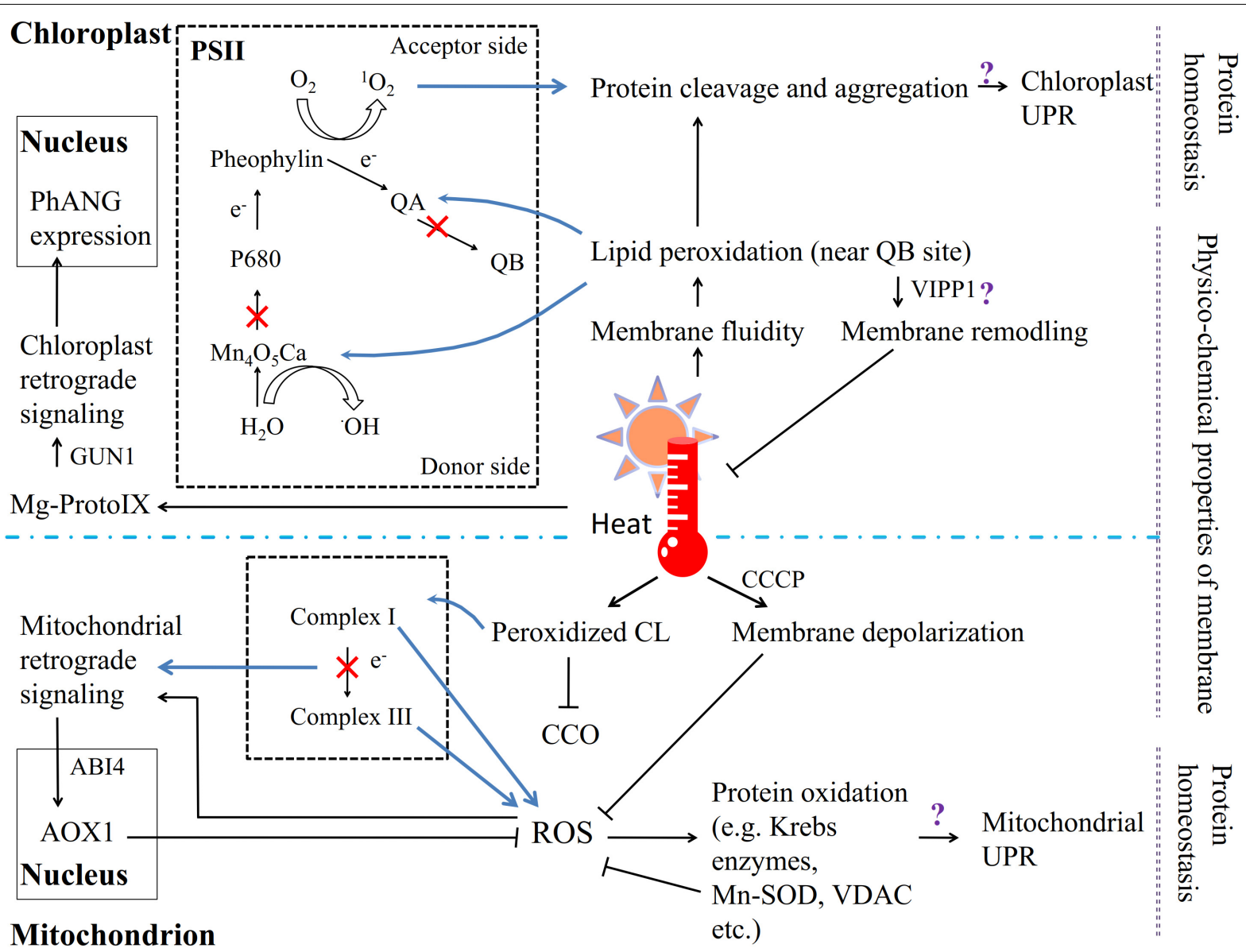

FIGURE 2 | The chloroplast and mitochondrion are involved in the response to heat stress in plants. Except the PM, the other key sites of ROS generation are PSII in chloroplasts and complex I/III in mitochondria. Heat affects the fluidity of the thylakoid membrane, and unsaturated lipids near the QB site are particularly vulnerable to peroxidation. The lipid peroxidation products affect the stability of photosystem proteins; the electron transport chain is restrained, and ${ }^{1} \mathrm{O}_{2}$ forms on the electron acceptor side and $\bullet \mathrm{OH}$ on the electron donor side. High temperatures trigger the chloroplast UPR and retrograde signaling pathway. Similarly, heat stress causes $\mathrm{CL}$ lipid peroxidation in the mitochondrion membrane, which inhibits the activity of CCO; but membrane depolarization via CCCP can inhibit ROS generation. The electron transport suppressed in the respiratory chain induces the production of ROS, which triggers both the mitochondrial UPR and retrograde signaling pathway. 
produced, which in turn causes D1 protein degradation via interactions with the protein (Pospíšil et al., 2007; Yamamoto et al., 2008; Yamashita et al., 2008; Pospíšil and Yamamoto, 2017). In addition, heat-induced lipid peroxidation can facilitate the denaturation and destabilization of PsbO (PsbP and PsbQ in spinach PSII) binding to the PSII core complex and promote manganese ion release from the $\mathrm{Mn}_{4} \mathrm{O}_{5} \mathrm{Ca}$ cluster, which has been demonstrated to be the main reason for the inactivation of electron transport on the donor side of PSII (Pospísil et al., 2003; Yamauchi et al., 2008; Yamauchi and Sugimoto, 2010; Pospíśil and Yamamoto, 2017). In maintaining the chloroplast membrane under heat stress, a remarkable role is played by the vesicle-inducing protein in plastid 1 (VIPP1), which localizes to the chloroplast envelope and thylakoid membrane (Zhang et al., 2016). VIPP1 was recently indicated to be a GTPase involved in maintaining the integrity of photosynthetic membranes via an effect on membrane remodeling when plants were subjected to stresses (Ohnishi et al., 2018).

Chloroplast retrograde signaling can be initiated by the accumulation of the chlorophyll intermediate $\mathrm{Mg}$ protoporphyrin IX (Mg-ProtoIX, belonging to tetrapyrroles), as shown by gun (genome uncoupled) mutants, which exhibit impaired communication from the chloroplast to the nucleus, controlling photosynthesis-associated nuclear gene (PhANG) expression (Susek et al., 1993; Mochizuki et al., 2001; Larkin et al., 2003; Strand et al., 2003; Koussevitzky et al., 2007; Woodson and Chory, 2008; Barajas-López Jde et al., 2013; Zhang et al., 2015; Figure 2). GUN1, which encodes a unique plastid-localized pentatricopeptide repeat (PPR) protein, has been shown to be required to transmit stress signaling to the nuclear transcription factor ABA insensitive 4 (ABI4; Koussevitzky et al., 2007). Additionally, ABI4 is considered to be a central regulator that is involved in many essential environmental signaling pathways and in the developmental as well as central metabolic processes of cells or organelles (reviewed by León et al., 2013). Findings in Chlamydomonas reinhardtii have further indicated that Mg-ProtoIX transiently promotes the expression of heat shock protein 70 (HSP70), which may localize to both the plastid and cytoplasm (Kropat et al., 1997, 2000). In addition, nuclear gene transcriptional studies on the above green alga showed that more than half of tetrapyrrole-interrelated genes were also activated by heat stress (Voss et al., 2011). Moreover, the chloroplast ribosomal protein S1 (RPS1) was reported to activate the expression of HSFA2, which is considered to regulate heat-stress-responsive genes during heat acclimation ( $\mathrm{Yu}$ et al., 2012; Liu and Charng, 2013).

\section{Mitochondria}

In the mitochondria, a type of phospholipid known as cardiolipin (CL), which has a high percentage of polyunsaturated fatty acids, is embedded in the mitochondrial membrane, where lipid peroxidation occurs (Bligny and Douce, 1980; Caiveau et al., 2001; Figure 2). Damaged CL strongly decreases the activity of cytochrome c oxidase (CCO) under stress (Paradies et al., 1998). Moreover, in A. thaliana, cardiolipin synthase (CLS) is required for mitochondrial morphogenesis and the response to hightemperature stress (Pan et al., 2014). The physical state of the mitochondrial membrane is also crucial; the depolarization of the mitochondrial membrane by the protonophore CCCP has been shown to inhibit ROS generation under thermal treatment (Fedyaeva et al., 2014). Additionally, the mitochondrion is one of the key compartments in ROS generation, especially when the rate of the electron transport chain has been decreased by environmental stresses (Møller and Kristensen, 2004). ROS negatively affect both lipids and proteins. The products of protein oxidation consist mostly of tryptophan (Taylor et al., 2003) and products of carbonylation and fragmentation (Sweetlove et al., 2002). For example, some Krebs cycle enzymes, other redox enzymes, and HSPs as well as Mn superoxide dismutase (MnSOD) and the voltage-dependent anion channel from rice leaf mitochondria, can be carbonylated under stress (Kristensen et al., 2004; Figure 2).

The mitochondrial retrograde signaling pathway also shows a relationship with ROS generation and accumulation (Rhoads et al., 2006; Rhoads and Subbaiah, 2007; Figure 2). When electron transport is disrupted by abiotic stresses, the increased expression of nuclear-encoded alternative oxidase 1 (AOX1) regulates the ROS level to trigger retrograde responses in plants. The $A O X 1 A$ promoter sequence is one of the targets of ABI4 in A. thaliana; ABI4 is involved in mitochondrion-to-nucleus retrograde signaling as well as that in chloroplasts (Giraud et al., 2009). Because mitochondrial complexes I and III are the primary sites of ROS generation, a mutation in complex I can promote ROS accumulation and decrease the expression of COR genes (Lee et al., 2002; Møller and Kristensen, 2004). Mitochondrionderived DEXH box RNA helicases or PPR proteins also induce ROS accumulation and are involved in ABA responses (He et al., 2012).

\section{Calcium lons and HSPs in Chloroplasts and Mitochondria}

The roles of $\mathrm{Ca}^{2+}$ and HSPs in the regulation of organelle signaling under high-temperature stress should not be ignored. Earlier studies showed that chloroplasts contained high total $\mathrm{Ca}^{2+}$ concentrations (Brand and Becker, 1984; Evans et al., 1991), while the potential of the plant inner mitochondrial membrane may affect the level of cytosolic $\mathrm{Ca}^{2+}$ and, thus, the expression of heat-responsive genes (Pyatrikas et al., 2014; Rikhvanov et al., 2014). However, further studies are needed in this field.

The HSPs exhibit a chaperone function, folding polypeptides into a mature state or preventing misfolded proteins from aggregation, and they have been found to accumulate in cells under thermal stress (Trösch et al., 2015). Because most proteins in chloroplasts and mitochondria are encoded by nuclear genes, and the polypeptides are exported from the nucleus to the organelles, HSPs are correspondingly required for the protein conformational changes during these processes. HSP70 acts upstream of other HSPs and cooperates with other chaperones in protein folding, refolding and disaggregation (Langer et al., 1992; Haslberger et al., 2007). Chloroplast stromal HSP70 was found to be involved in PSII repair under stress and to be affected by the redox state of the chloroplast (Schroda et al., 1999; Liu et al., 2007b; Rutgers and Schroda, 2013; Trösch et al., 2015). Another HSP, HSP90, more likely serves as a regulator 
of signal transfer to the nucleus, including the modulation of photosynthesis-related genes and stress-related genes (Beck, 2005; Trösch et al., 2015), although it can also stabilize unfolded proteins (Nathan et al., 1997). The sHSPs are chaperones that show high diversity among species and tissues and can prevent improper protein aggregation and partially unfold under stress conditions (Bernfur et al., 2017). Several lines of evidence have suggested that a small chloroplast HSP, HSP21, is involved in plant adaptations to heat stress and oxidative stress (Heckathorn et al., 1998; Shakeel et al., 2011; Kim et al., 2012). A recent study demonstrated that HSP21 could bind to and stabilize PSII core proteins D1 and D2 under heat stress, which was activated by the GUN5-associated retrograde signaling pathway (Chen et al., 2017). GUN5 encodes an Mg chelatase that can insert $\mathrm{Mg}^{2+}$ into the protoporphyrin ring during tetrapyrrole biosynthesis, which regulates ROS-induced gene expression (Mochizuki et al., 2001; Adhikari et al., 2011). Furthermore, HSP21 was demonstrated to interact with another protein, plastid transcriptionally active 5 (pTAC5), which is required for plastid-encoded RNA polymerase (PEP)-dependent transcription, and the latter protein plays a crucial role in plastid development under heat stress (Zhong et al., 2013).

\section{ER STRESS AND THE UNFOLDED PROTEIN RESPONSE ARE INVOLVED IN PLANT ADAPTIVE RESPONSES TO HIGH TEMPERATURES}

\section{ER Stress}

The ER is the largest endomembrane system, and it is responsible for protein synthesis, folding, modification and export as well as lipid metabolism. More than a third of the total proteins pass through the secretory pathway via the ER lumen (Ron and Walter, 2007; Fragkostefanakis et al., 2016). Therefore, ER homeostasis is highly susceptible to environmental cues, inevitably resulting in the production of misfolded proteins or the accumulation of unfolded proteins, which are also known as ER stress (Walter and Ron, 2011). The mechanism underlying the response to ER stress at the transcriptional and translational levels is referred to as the unfolded protein response (UPR), which includes the detection of unfolded or misfolded proteins; the activation of chaperones, foldases and pertinent factors; and the reduction of the secreted and membrane protein contents. If the UPR is overextended and ER homeostasis cannot be sustained, cells will initiate programmed death (Deng et al., 2013). In addition to aberrant proteins, instability of phospholipid metabolism also leads to ER stress and activates the UPR (Yu et al., 2018). Studies on yeast and mammalian cells revealed that an imbalanced $\mathrm{PC}$ to $\mathrm{PE}$ ratio is a crucial cause of ER stress (Fu et al., 2011; Thibault et al., 2012; Gao et al., 2015). However, the link between lipid functions and the ER stress response is still poorly understood in plants. Yu et al. (2018) verified that Arabidopsis glycerolipid homeostasis might be sustained at the post-transcriptional level under ER stress. Additionally, a study on maize illustrated that ER stress could affect the enzyme activity of diacylglycerol kinase (DGA), choline phosphate cytidylyltransferase, phosphatidylinositol-4kinase, and PIPK (Shank et al., 2001).

\section{ER Stress Sensors Perceive High-Temperature Stress}

Nascent proteins require molecular chaperones to prevent their aggregation and assist in their folding into functional conformations. Binding protein (BiP), an HSP70, is a common chaperone in the ER that is recruited by the DNAJ protein ERdj3 to bind unfolded proteins (Jin et al., 2009; Figure 1). Other chaperones known as foldases have also been described in several previous reviews (Gupta and Tuteja, 2011; Deng et al., 2013).

Plants harbor two primary signaling pathways that have been reported to sense ER stress. One is aided by membrane-associated transcription factors (the basic leucine zipper transcription factors bZIP17 and bZIP28), and the other involves an RNA splicing factor (the inositol-requiring enzyme IRE1) (Liu and Howell, 2016; Figure 1). The bZIP28 can specifically sense heattriggered ER stress via $\mathrm{BiP}$, after which it translocated into the Golgi, and its TF domain on the cytosol side can be cleaved by proteolytic processing. The TF portion subsequently enters the nucleus to activate the expression of stress-related genes. In addition, IRE1 is activated by interaction with unfolded proteins and then recognizes and splices the mRNA of bZIP60, after which the splicing products enter the nucleus to trigger the expression of UPR genes (Deng et al., 2011; Liu and Howell, 2016; Figure 1). Heat stress has been validated as a direct and efficient factor that influences the nuclear relocation of bZIP28 and the mRNA splicing of bZIP60 (Che et al., 2010; Deng et al., 2011).

\section{CONCLUSION AND PERSPECTIVE}

Temperature fluctuation is an unusual ambient signal that causes concurrent alterations in multiple cellular compartments, including the PM, cytosol, energy-associated organelles and chromatin (Zhu, 2016). In fact, there is widespread support for the notion that an increase in PM fluidity as induced by high temperatures first activates stress-signaling pathways (reviewed by Ruelland and Zachowski, 2010). However, how should the concept of "primary heat sensors" be understood? If the macromolecules in plant cells are defined as thermosensors that are able to not only precisely perceive various temperature changes but also differentially trigger specific signaling pathways (Mittler et al., 2012), the most feasible strategy might be to first divert ambient temperature signals into different cell signaling patterns before they are perceived by sensors. From this perspective, the specific role of the membrane might be to serve as both a thermometer and a stress encoder. Additionally, subtle changes in the lipid composition of fatty acid chains or head groups can alter both the membrane properties and the interaction with specific proteins and even the membrane substructures (microdomains), which are highly sensitive to environmental perturbation (Barrero-Sicilia et al., 2017); 
in this context, the membrane clearly meets the requirement for encoding stress. Of course, more evidence must be obtained and evaluated to dissect the mechanisms of membraneassociated stress sensing and signaling. One important reason why it is so difficult to study these mechanisms is that membrane structures in plant cells possessing a cell wall exhibit an enormous variety of membrane components with diverse localizations, interactions, and functions (Escribá et al., 2008; Malinsky et al., 2013). The conventional methods for the investigation of membrane proteins have obvious limitations (e.g., specific protein associations can be disrupted by detergents; Tanner et al., 2011; Malinsky et al., 2013). The other reason is that the available studies on lipids and relevant enzymes are not equivalent to the attention paid to the proteins involved in signal transduction (Eyster, 2007), despite the fact that membrane lipids show the best fit for the response to various environmental cues among these molecules (Escribá et al., 2008). Fortunately, the direct visualization of the distribution of membrane constituents that rely on fluorescence microscopy approaches makes it possible to detect the dynamic interaction and distribution of PM substructures (reviewed by Malinsky et al., 2013; Konrad and Ott, 2015; Wang et al., 2018). In addition, based on improvements in the sensitivity and accuracy of mass spectrometry and chromatography as well as microarray transcriptome analyses, it is possible to obtain knowledge of the entire lipidome and the complicated regulatory network at a certain time point in an individual tissue type under stresses (Cacas et al., 2012; Higashi et al., 2015; Marla et al., 2017).

Furthermore, numerous vesicles in cells are also an important part of the membrane system whose formation and trafficking in plants have been shown to be involved in membrane repair under abiotic and biotic stresses (reviewed by Hadlington and Denecke, 2000; Frei and Robatzek, 2009; Baral et al., 2015). However, much about the underlying mechanism of communication between extra-membrane and membranous organelles remains to be elucidated. Moreover, heat stress is inevitably associated with various other stresses during actual crop production. For example, high temperatures are often accompanied by high light, which can accelerate the plant injury inflicted by drought and salinity stress in inland regions. Elevated temperatures have also been shown to promote the infection of plant cells by pathogens and cause damage to SA defense (Huot et al., 2017). The identification and elucidation of these "crosstalk" mechanisms seem precisely the task of the day.

In short, although studies on the underlying mechanisms of plant adaptation to high temperature and the engineering of crop

\section{REFERENCES}

Adhikari, N. D., Froehlich, J. E., Strand, D. D., Buck, S. M., Kramer, D. M., and Larkin, R. M. (2011). GUN4-porphyrin complexes bind the ChlH/ GUN5 subunit of Mg-Chelatase and promote chlorophyll biosynthesis in Arabidopsis. Plant Cell 23, 1449-1467. doi: 10.1105/tpc.110. 082503 plants with higher thermotolerance are making steady progress, many questions are still open and need to be further addressed. Important issues include the following:

(i) Are other primary thermosensors present in the PM or other intracellular compartments that synergistically trigger multiple and/or specific responses?

(ii) How is the signaling that is triggered by various forms, durations and intensities of high-temperature stress transmitted?

(iii) What precise role do membrane microdomains play in the plant HR?

(iv) How can the dynamic remodeling of membranes under various heat stresses be recorded or mimicked?

(v) How do second messengers transmit multiple signals to downstream components of HS signal transduction chains?

(vi) How do the UPR in chloroplasts, the cytosol and the ER coordinately and collaboratively function in protein homeostasis?

(vii) How does the PM contact other membranous organelles under elevated temperatures?

(viii) How does the lipid metabolism in chloroplasts and the ER participate in membrane sensing and remodeling during the rapid HR?

(ix) Apart from HSF-HSP responses, are there other HSR effectors that switch the comprehensive responses on/off in plant cells?

(x) How is heat stress sensing distinguished from and integrated with the sensing of other stresses?

\section{AUTHOR CONTRIBUTIONS}

YN prepared and wrote this manuscript. YX contributed by organizing and reviewing a major part of the manuscript.

\section{FUNDING}

This work was supported by the National Natural Science Foundation of China (31400220) and the Fundamental Research Funds for the Central Universities (lzujbky-2014-92, lzujbky2017-156, and lzujbky-2017-kb05).

\section{ACKNOWLEDGMENTS}

We thank the editor and reviewers for their helpful comments and their input. mechanism conserved from bacteria to humans. Mol. Microbiol. 62, 1507-1514. doi: 10.1111/j.1365-2958.2006.05484.x

Andersen, J. P., Vestergaard, A. L., Mikkelsen, S. A., Mogensen, L. S., Chalat, M., and Molday, R. S. (2016). P4-ATPases as phospholipid flippasesstructure, function, and enigmas. Front. Physiol. 7:275. doi: 10.3389/fphys.2016. 00275 
Arispe, N., Doh, M., and De Maio, A. (2002). Lipid interaction differentiates the constitutive and stress-induced heat shock proteins Hsc70 and Hsp70. Cell Stress Chaperones 7, 330-338. doi: 10.1379/1466-1268(2002)007<0330: LIDTCA $>2.0 . \mathrm{CO} ; 2$

Asada, K. (2006). Production and scavenging of reactive oxygen species in chloroplasts and their functions. Plant Physiol. 141, 391-396. doi: 10.1104/pp. 106.082040

Axelsen, K. B., and Palmgren, M. G. (1998). Evolution of substrate specificities in the P-type ATPase superfamily. J. Mol. Evol. 46, 84-101. doi: 10.1007/ PL00006286

Bahuguna, R. N., Jha, J., Pal, M., Shah, D., Lawas, L. M., Khetarpal, S., et al. (2015). Physiological and biochemical characterization of NERICA-L-44: a novel source of heat tolerance at the vegetative and reproductive stages in rice. Physiol. Plant 154, 543-559. doi: 10.1111/ppl.12299

Baniwal, S. K., Bharti, K., Chan, K. Y., Fauth, M., Ganguli, A., Kotak, S., et al. (2004). Heat stress response in plants: a complex game with chaperones and more than twenty heat stress transcription factors. J. Biosci. 29, 471-487. doi: 10.1007/BF02712120

Baniwal, S. K., Chan, K. Y., Scharf, S. K., and Nover, L. (2007). Role of heat stress transcription factor HsfA5 as specific repressor of HsfA4. J. Biol. Chem. 282, 3605-3613. doi: 10.1074/jbc.M609545200

Barajas-López Jde, D., Blanco, N. E., and Strand, Å. (2013). Plastid-to-nucleus communication, signals controlling the running of the plant cell. Biochim. Biophys. Acta 1833, 425-437. doi: 10.1016/j.bbamcr.2012.06.020

Baral, A., Shruthi, K. S., and Mathew, M. K. (2015). Vesicular trafficking and salinity responses in plants. IUBMB Life 67, 677-686. doi: 10.1002/iub.1425

Barrero-Sicilia, C., Silvestre, S., Haslam, R. P., and Michaelson, L. V. (2017). Lipid remodelling: unravelling the response to cold stress in Arabidopsis and its extremophile relative Eutrema salsugineum. Plant Sci. 263, 194-200. doi: 10.1016/j.plantsci.2017.07.017

Beck, C. F. (2005). Signaling pathways from the chloroplast to the nucleus. Planta 222, 743-756. doi: 10.1007/s00425-005-0021-2

Bernfur, K., Rutsdottir, G., and Emanuelsson, C. (2017). The chloroplast-localized small heat shock protein Hsp21 associates with the thylakoid membranes in heat-stressed plants. Protein Sci. 26, 1773-1784. doi: 10.1002/pro.3213

Bita, C. E., and Gerats, T. (2013). Plant toleranc to high temperature in a changing environment: scientific fundamentals and production of heat stress-tolerant crops. Front. Plant Sci. 4:273. doi: 10.3389/fpls.2013.00273

Bligny, R., and Douce, R. (1980). Precise localization of cardiolipin in plant cells. Biochim. Biophys. Acta 617, 254-263. doi: 10.1016/0005-2760(80)90168-X

Bokszczanin, K. L., Solanaceae Pollen Thermotolerance Initial Training Network (Spot-Itn) Consortium, and Fragkostefanakis, S. (2013). Perspectives on deciphering mechanisms underlying plant heat stress response and thermotolerance. Front. Plant Sci. 4:315. doi: 10.3389/fpls.2013.00315

Botella, C., Sautron, E., Boudiere, L., Michaud, M., Dubots, E., and Yamaryo-Botté, Y. (2016). ALA10, a phospholipid flippase, controls FAD2/FAD3 desaturation of phosphatidylcholine in the ER and affects chloroplast lipid composition in Arabidopsis thaliana. Plant Physiol. 170, 1300-1314. doi: 10.1104/pp.15. 01557

Braam, J. (1992). Regulated expression of the calmodulin-related TCH genes in cultured Arabidopsis cells: induction by calcium and heat shock. Proc. Natl. Acad. Sci. U.S.A. 89, 3213-3216. doi: 10.1073/pnas.89.8.3213

Brand, J. J., and Becker, D. W. (1984). Evidence for direct roles of calcium in photosynthesis. J. Bioenerg. Biomembr. 16, 239-249. doi: 10.1007/BF00744278

Brown, D. A., and Rose, J. K. (1992). Sorting of GPI-anchored proteins to glycolipid-enriched membrane subdomains during transport to the apical cell surface. Cell 68, 533-544. doi: 10.1016/0092-8674(92)90189-J

Browse, J., and Somerville, C. (1991). Glycerolipid synthesis: biochemistry and regulation. Annu. Rev. Plant Physiol. Plant. Mol. Biol. 42, 467-506. doi: 10.1146/ annurev.pp.42.060191.002343

Buchanan, B. B., Gruissem, W., and Jones, R. L. (2015). Biochemistry and Molecular Biology of Plants. West Sussex: Wiley Blackwell Press.

Cacas, J. L., Furt, F., Le Guédard, M., Schmitter, J. M., Buré, C., Gerbeau-Pissot, P., et al. (2012). Lipids of plant membrane rafts. Prog. Lipid Res. 51, 272-299. doi: 10.1016/j.plipres.2012.04.001

Caiveau, O., Fortune, D., Cantrel, C., Zachowski, A., and Moreau, F. (2001). Consequences of omega-6-oleate desaturase deficiency on lipid dynamics and functional properties of mitochondrial membranes of Arabidopsis thaliana. J. Biol. Chem. 276, 5788-5794. doi: 10.1074/jbc.M006231200

Chan, T., Shimizu, Y., Pospíšil, P., Nijo, N., Fujiwara, A., Taninaka, Y., et al. (2012). Quality control of photosystem II: lipid peroxidation accelerates photoinhibition under excessive illumination. PLoS One 7:e52100. doi: 10.1371/ journal.pone. 0052100

Che, P., Bussell, J. D., Zhou, W., Estavillo, G. M., Pogson, B. J., and Smith, S. M. (2010). Signaling from the endoplasmic reticulum activates brassinosteroid signaling and promotes acclimation to stress in Arabidopsis. Sci. Signal. 3:ra69. doi: 10.1126/scisignal.2001140

Chen, S. T., He, N. Y., Chen, J. H., and Guo, F. Q. (2017). Identification of core subunits of photosystem II as action sites of HSP21, which is activated by the GUN5-mediated retrograde pathway in Arabidopsis. Plant J. 89, 1106-1118. doi: $10.1111 /$ tpj.13447

Chen, T. H. H. (1994). Plant adaptation to low temperature stress. Can. J. Plant Pathol. 16, 231-236. doi: 10.1080/07060669409500760

Chinnusamy, V., Ohta, M., Kanrar, S., Lee, B. H., Hong, X., Agarwal, M., et al. (2003). ICE1: a regulator of cold-induced transcriptome and freezing tolerance in Arabidopsis. Genes Dev. 17, 1043-1054. doi: 10.1101/gad.1077503

Chinnusamy, V., Zhu, J., and Zhu, J. K. (2007). Cold stress regulation of gene expression in plants. Trends Plant Sci. 12, 444-451. doi: 10.1016/j.tplants.2007. 07.002

Cook, D., Fowler, S., Fiehn, O., and Thomashow, M. F. (2004). A prominent role for the CBF cold response pathway in configuring the low-temperature metabolome of Arabidopsis. Proc. Natl. Acad. Sci. U.S.A. 101, 15243-15248. doi: 10.1073/pnas.0406069101

Cossani, C. M., and Reynolds, M. P. (2012). Physiological traits for improving heat tolerance in wheat. Plant Physiol. 160, 1710-1718. doi: 10.1104/pp.112.207753

Deng, Y., Humbert, S., Liu, J. X., Srivastava, R., Rothstein, S. J., and Howell, S. H. (2011). Heat induces the splicing by IRE1 of a mRNA encoding a transcription factor involved in the unfolded protein response in Arabidopsis. Proc. Natl. Acad. Sci. U.S.A. 108, 7247-7252. doi: 10.1073/pnas.1102117108

Deng, Y., Srivastava, R., and Howell, S. H. (2013). Endoplasmic reticulum (ER) stress response and its physiological roles in plants. Int. J. Mol. Sci. 14, 8188-8212. doi: 10.3390/ijms14048188

Dhanda, S. S., and Munjal, R. (2012). Heat tolerance in relation to acquired thermotolerance for membrane lipids in bread wheat. Field Crops Res. 135, 30-37. doi: 10.1016/j.fcr.2012.06.009

Di Paolo, G., and De Camilli, P. (2006). Phosphoinositides in cell regulation and membrane dynamics. Nature 443, 651-657. doi: 10.1038/nature05185

Doherty, C. J., Van Buskirk, H. A., Myers, S. J., and Thomashow, M. F. (2009). Roles for Arabidopsis CAMTA transcription factors in cold-regulated gene expression and freezing tolerance. Plant Cell 21, 972-984. doi: 10.1105/tpc.108.063958

Dorne, A. J., Joyard, J., and Douce, R. (1990). Do thylakoids really contain phosphatidylcholine? Proc. Natl. Acad. Sci. U.S.A. 87, 71-74. doi: 10.1073/pnas. 87.1.71

Dubots, E., Botté, C., Boudière, L., Yamaryo-Botté, Y., Jouhet, J., Maréchal, E., et al. (2012). Role of phosphatidic acid in plant galactolipid synthesis. Biochimie 94, 86-93. doi: 10.1016/j.biochi.2011.03.012

Dyer, J. M., and Mullen, R. T. (2001). Immunocytological localization of two plant fatty acid desaturases in the endoplasmic reticulum. FEBS Lett. 494, 44-47. doi: 10.1016/S0014-5793(01)02315-8

Enrique Gomez, R., Joubès, J., Valentin, N., Batoko, H., Satiat-Jeunemaître, B., and Bernard, A. (2017). Lipids in membrane dynamics during autophagy in plants. J. Exp. Bot. 69, 1287-1299. doi: 10.1093/jxb/erx392

Escribá, P. V., González-Ros, J. M., Goñi, F. M., Kinnunen, P. K., Vigh, L., SánchezMagraner, L., et al. (2008). Membranes: a meeting point for lipids, proteins and therapies. J. Cell Mol. Med. 12, 829-875. doi: 10.1111/j.1582-4934.2008.00281.x

Evans, D. E., Briars, S. A., and Williams, L. E. (1991). Active Ca2 ${ }^{+}$-transport by plant cell membranes. J. Exp. Bot. 42, 285-303. doi: 10.1093/jxb/42.3.285

Eyster, K. M. (2007). The membrane and lipids as integral participants in signal transduction: lipid signal transduction for the non-lipid biochemist. $A d v$. Physiol. Educ. 31, 5-16. doi: 10.1152/advan.00088.2006

Fedyaeva, A. V., Stepanov, A. V., Lyubushkina, I. V., Pobezhimova, T. P., and Rikhvanov, E. G. (2014). Heat shock induces production of reactive oxygen species and increases inner mitochondrial membrane potential in winter wheat cells. Biochemistry 79, 1202-1210. doi: 10.1134/S0006297914110078 
Fowler, S., and Thomashow, M. F. (2002). Arabidopsis transcriptome profiling indicates that multiple regulatory pathways are activated during cold acclimation in addition to the CBF cold response pathway. Plant Cell 14, 1675-1690. doi: 10.1105/tpc.003483

Fragkostefanakis, S., Mesihovic, A., Hu, Y., and Schleiff, E. (2016). Unfolded protein response in pollen development and heat stress tolerance. Plant Reprod. 29, 81-91. doi: 10.1007/s00497-016-0276-8

Frei, N. F. D., and Robatzek, S. (2009). Trafficking vesicles: pro or contra pathogens? Curr. Opin. Plant Biol. 12, 437-443. doi: 10.1016/j.pbi.2009. 06.002

Fu, S., Yang, L., Li, P., Hofmann, O., Dicker, L., Hide, W., et al. (2011). Aberrant lipid metabolism disrupts calcium homeostasis causing liver endoplasmic reticulum stress in obesity. Nature 473, 528-531. doi: 10.1038/nature09968

Fujimoto, T., and Parmryd, I. (2017). Interleaflet coupling, pinning, and leaflet asymmetry-major players in plasma membrane nanodomain formation. Front. Cell Dev. Biol. 4:155. doi: 10.3389/fcell.2016.00155

Furt, F., Simon-Plas, F., and Mongrand, S. (2011). "Lipids of the plant plasma membrane," in The Plant Plasma Membranes, eds A. S. Murphy, B. Schulz, and W. Peer (Berlin: Springer Press), 3-30. doi: 10.1007/978-3-642-13431-9_1

Gao, F., Han, X., Wu, J., Zheng, S., Shang, Z., Sun, D., et al. (2012). A heatactivated calcium-permeable channel-Arabidopsis cyclic nucleotide-gated ion channel 6 - is involved in heat shock responses. Plant J. 70, 1056-1069. doi: 10.1111/j.1365-313X.2012.04969.x

Gao, X., van der Veen, J. N., Vance, J. E., Thiesen, A., Vance, D. E., and Jacobs, R. L. (2015). Lack of phosphatidylethanolamine N-methyltransferase alters hepatic phospholipid composition and induces endoplasmic reticulum stress. Biochim. Biophys. Acta 1852, 2689-2699. doi: 10.1016/j.bbadis.2015.09.006

Gascard, P., Tran, D., Sauvage, M., Sulpice, J. C., Fukami, K., Takenawa, T., et al. (1991). Asymmetric distribution of phosphoinositides and phosphatidic acid in the human erythrocyte membrane. Biochim. Biophys. Acta 1069, 27-36. doi: 10.1016/0005-2736(91)90100-M

Giraud, E., Van Aken, O., Ho, L. H., and Whelan, J. (2009). The transcription factor ABI4 is a regulator of mitochondrial retrograde expression of ALTERNATIVE OXIDASE1a. Plant Physiol. 150, 1286-1296. doi: 10.1104/pp.109.139782

Gomès, E., Jakobsen, M. K., Axelsen, K. B., Geisler, M., and Palmgren, M. G. (2000). Chilling tolerance in Arabidopsis involves ALA1, a member of a new family of putative aminophospholipid translocases. Plant Cell 12, 2441-2454. doi: $10.1105 /$ tpc.12.12.2441

Gong, M., van der Luit, A., Knight, M., and Trewavas, A. (1998). Heat-shock induces changes in intracellular $\mathrm{Ca} 2+$ level in tobacco seedlings in relation to thermotolerance. Plant Physiol. 116, 429-437. doi: 10.1104/pp.116.1.429

Grover, A., Agarwal, M., Katiyar-Agarwal, S., Sahi, C., and Agarwal, S. (2000). Production of high temperature tolerant transgenic plants through manipulation of membrane lipids. Curr. Sci. 79, 557-559.

Guo, L. (2011). Phosphatidic acid binds and stimulates Arabidopsis sphingosine kinases. J. Biol. Chem. 286, 13336-13345. doi: 10.1074/jbc.M110.190892

Gupta, D., and Tuteja, N. (2011). Chaperones and foldases in endoplasmic reticulum stress signaling in plants. Plant Signal. Behav. 6, 232-236. doi: 10. 4161/psb.6.2.15490

Gupta, K. J., Hincha, D. K., and Mur, L. A. (2011). No way to treat a cold. New Phytol. 189, 360-363. doi: 10.1111/j.1469-8137.2010.03586.x

Guy, C. (1999). Molecular responses of plants to cold shock and cold acclimation. J. Mol. Microbiol. Biotechnol. 1, 231-242.

Guy, C. L. (1990). Cold acclimation and freezing stress tolerance role of protein metabolism. Annu. Rev. Plant Physiol. Plant Mol. Biol. 41, 187-223. doi: 10. 1146/annurev.pp.41.060190.001155

Hadlington, J. L., and Denecke, J. (2000). Sorting of soluble proteins in the secretory pathway of plants. Curr. Opin. Plant Biol. 3, 461-468. doi: 10.1016/S13695266(00)00114-X

Hannah, M. A., Heyer, A. G., and Hincha, D. K. (2005). A global survey of gene regulation during cold acclimation in Arabidopsis thaliana. PLoS Genet. 1:e26. doi: 10.1371/journal.pgen.0010026

Hao, H., Fan, L., Chen, T., Li, R., Li, X., He, Q., et al. (2014). Clathrin and membrane microdomains cooperatively regulate $\mathrm{RbohD}$ dynamics and activity in Arabidopsis. Plant Cell 26, 1729-1745. doi: 10.1105/tpc.113.122358

Haslberger, T., Weibezahn, J., Zahn, R., Lee, S., Tsai, F. T., Bukau, B., et al. (2007). $\mathrm{M}$ domains couple the $\mathrm{ClpB}$ threading motor with the DnaK chaperone activity. Mol. Cell 25, 247-260. doi: 10.1016/j.molcel.2006.11.008
He, J., Duan, Y., Hua, D., Fan, G., Wang, L., Liu, Y., et al. (2012). DEXH box RNA helicase-mediated mitochondrial reactive oxygen species production in Arabidopsis mediates crosstalk between abscisic acid and Auxin signaling. Plant Cell 24, 1815-1833. doi: 10.1105/tpc.112.098707

Heckathorn, S. A., Downs, C. A., Sharkey, T. D., and Coleman, J. S. (1998). The small, methionine-rich chloroplast heat-shock protein protects photosystem II electron transport during heat stress. Plant Physiol. 116, 439-444. doi: 10.1104/ pp.116.1.439

Heinz, E. (1993). "Biosynthesis of polyunsaturated fatty acids," in Lipid Metabolism in Plants, ed. T. S. Moore (Boca Raton, FL: CRC Press), 33-90.

Hemme, D., Veyel, D., Muhlhaus, T., Sommer, F., Jüppner, J., Unger, A. K., et al. (2014). Systems-wide analysis of acclimation responses to long-term heat stress and recovery in the photosynthetic model organism Chlamydomonas reinhardtii. Plant Cell 26, 4270-4297. doi: 10.1105/tpc.114.130997

Higashi, Y., Okazaki, Y., Myouga, F., Shinozaki, K., and Saito, K. (2015). Landscape of the lipidome and transcriptome under heat stress in Arabidopsis thaliana. Sci. Rep. 5:10533. doi: 10.1038/srep10533

Horiguchi, G., Fuse, T., Kawakami, N., Kodama, H., and Iba, K. (2000). Temperature dependent translational regulation of the ER omega-3 fatty acid desaturase gene in wheat root tips. Plant J. 24, 805-813. doi: 10.1111/j.1365313X.2000.00925.X

Huot, B., Castroverde, C. D. M., Velásquez, A. C., Hubbard, E., Pulman, J. A., Yao, J., et al. (2017). Dual impact of elevated temperature on plant defence and bacterial virulence in Arabidopsis. Nat. Commun. 8:1808. doi: 10.1038/s41467017-01674-2

Iba, K. (2002). Acclimative response to temperature stress in higher plants: approaches of gene engineering for temperature tolerance. Annu. Rev. Plant Biol. 53, 225-245. doi: 10.1146/annurev.arplant.53.100201.160729

Intergovernmental Panel on Climate Change [IPCC] (2014a). Climate Change 2014: Synthesis Report. Contribution of Working Groups I, II and III to the Fifth Assessment Report of the Intergovernmental Panel on Climate Change. Geneva: IPCC, 151.

Intergovernmental Panel on Climate Change [IPCC] (2014b). Food Security and Food Production System," in Climate Change 2014: Impacts, Adaptation and Vulnerability. Part A: Global and Sectoral Aspects. Contribution of Working Group II to the Fifth Assessment Report of the Intergovernmental Panel on Climate Change. Cambridge: Cambridge University Press, 485-533.

Jacobson, K., Mouritsen, O. G., and Anderson, R. G. (2007). Lipid rafts: at a crossroad between cell biology and physics. Nat. Cell Biol. 9, 7-14. doi: 10.1038/ ncb0107-7

Jagadish, S. V., Murty, M. V., and Quick, W. P. (2015). Rice responses to rising temperatures-challenges, perspectives and future directions. Plant Cell Environ. 38, 1686-1698. doi: 10.1111/pce.12430

Jarsch, I. K., Konrad, S. S., Stratil, T. F., Urbanus, S. L., Szymanski, W., Braun, P., et al. (2014). Plasma membranes are subcompartmentalized into a plethora of coexisting and diverse microdomains in Arabidopsis and Nicotiana benthamiana. Plant Cell 26, 1698-1711. doi: 10.1105/tpc.114.124446

Jin, Y., Zhuang, M., and Hendershot, L. M. (2009). ERdj3, a luminal ER DnaJ homologue, binds directly to unfolded proteins in the mammalian ER: identification of critical residues. Biochemistry 48, 41-49. doi: 10.1021/ bi8015923

Kachroo, A., Venugopal, S. C., Lapchyk, L., Falcone, D., Hildebrand, D., and Kachroo, P. (2004). Oleic acid levels regulated by glycerolipid metabolism modulate defense gene expression in Arabidopsis. Proc. Natl. Acad. Sci. U.S.A. 101, 5152-5157. doi: 10.1073/pnas.0401315101

Kaplan, F., Kopka, J., Haskell, D. W., Zhao, W., Schiller, K. C., Gatzke, N., et al. (2004). Exploring the temperature-stress metabolome of Arabidopsis. Plant Physiol. 136, 4159-4168. doi: 10.1104/pp.104.052142

Karnovsky, M. J., Kleinfeld, A. M., Hoover, R. L., and Klausner, R. D. (1982). The concept of lipid domains in membranes. J. Cell Biol. 94, 1-6. doi: 10.1083/jcb. 94.1.1

Khuu, N., Gidda, S., Shockey, J. M., Dyer, J. M., and Mullen, R. T. (2011). The $\mathrm{N}$ termini of Brassica and tung omega- 3 fatty acid desaturases mediate proteasome-dependent protein degradation in plant cells. Plant Signal. Behav. 6, 422-425. doi: 10.4161/psb.6.3.14522

Kim, K. H., Alam, I., Kim, Y. G., Sharmin, S. A., Lee, K. W., Lee, S. H., et al. (2012). Overexpression of a chloroplast-localized small heat shock protein OsHSP26 confers enhanced tolerance against oxidative and heat 
stresses in tall fescue. Biotechnol. Lett. 34, 371-377. doi: 10.1007/s10529-0110769-3

Kodama, H., Horiguchi, G., Nishiuchi, T., Nishimura, M., and Iba, K. (1995). Fatty acid desaturation during chilling acclimatization is one of the factors involved in conferring low-temperature tolerance to young tobacco leaves. Plant Physiol. 107, 1177-1185. doi: 10.1104/pp.107.4.1177

Konigshofer, H., Tromballa, H. W., and Loppert, H. G. (2008). Early events in signalling high-temperature stress in tobacco BY2 cells involve alterations in membrane fluidity and enhanced hydrogen peroxide production. Plant Cell Environ. 31, 1771-1780. doi: 10.1111/j.1365-3040.2008.01880.x

Konrad, S. S., and Ott, T. (2015). Molecular principles of membrane microdomain targeting in plants. Trends Plant Sci. 20, 351-361. doi: 10.1016/j.tplants.2015. 03.016

Kotak, S., Larkindale, J., Lee, U., von Koskull-Döring, P., Vierling, E., and Scharf, K. D. (2007). Complexity of the heat stress response in plants. Curr. Opin. Plant Biol. 10, 310-316. doi: 10.1016/j.pbi.2007.04.011

Koussevitzky, S., Nott, A., Mockler, T. C., Hong, F., Sachetto-Martins, G., Surpin, M., et al. (2007). Signals from chloroplasts converge to regulate nuclear gene expression. Science 316, 715-719. doi: 10.1126/science.1140516

Kristensen, B. K., Askerlund, P., Bykova, N. V., Egsgaard, H., and Møller, I. M. (2004). Identification of oxidized proteins in the matrix of rice leaf mitochondria by immunoprecipitation and two-dimensional liquid chromatography-tandem mass spectrometry. Phytochemistry 65, 1839-1851. doi: 10.1016/j.phytochem.2004.04.007

Kropat, J., Oster, U., Rudiger, W., and Beck, C. F. (1997). Chlorophyll precursors are signals of chloroplast origin involved in light induction of nuclear heatshock genes. Proc. Natl. Acad. Sci. U.S.A. 94, 14168-14172. doi: 10.1073/pnas. 94.25.14168

Kropat, J., Oster, U., Rudiger, W., and Beck, C. F. (2000). Chloroplast signalling in the light induction of nuclear HSP70 genes requires the accumulation of chlorophyll precursors and their accessibility to cytoplasm/nucleus. Plant J. 24, 523-531. doi: 10.1111/j.1365-313X.2000.00898.x

Kusumi, A., Fujiwara, T. K., Chadda, R., Xie, M., Tsunoyama, T. A., Kalay, Z., et al. (2012). Dynamic organizing principles of the plasma membrane that regulate signal transduction: commemorating the fortieth anniversary of Singer and Nicolson's fluid mosaic model. Annu. Rev. Cell Dev. Biol. 28, 215-250. doi: 10.1146/annurev-cellbio-100809-151736

Kusumi, A., Nakada, C., Ritchie, K., Murase, K., Suzuki, K., Murakoshi, H., et al. (2005). Paradigm shift of the plasma membrane concept from the two-dimensional continuum fluid to the partitioned fluid: high-speed singlemolecule tracking of membrane molecules. Annu. Rev. Biophys. Biomol. Struct. 34, 351-378. doi: 10.1146/annurev.biophys.34.040204.144637

Kusumi, A., Suzuki, K. G., Kasai, R. S., Ritchie, K., and Fujiwara, T. K. (2011). Hierarchical mesoscale domain organization of the plasma membrane. Trends Biochem. Sci. 36, 604-615. doi: 10.1016/j.tibs.2011.08.001

Lamosa, P., Burke, A., Peist, R., Huber, R., Liu, M. Y., Silva, G., et al. (2000). Thermostabilization of proteins by diglycerol phosphate, a new compatible solute from the hyperthermophile Archaeoglobus fulgidus. Appl. Environ. Microbiol. 66, 1974-1979. doi: 10.1128/AEM.66.5.1974-1979.2000

Langer, T., Lu, C., Echols, H., Flanagan, J., Hayer, M. K., and Hartl, F. U. (1992). Successive action of DnaK, DnaJ and GroEL along the pathway of chaperonemediated protein folding. Nature 356, 683-689. doi: 10.1038/356683a0

Larkin, R. M., Alonso, J. M., Ecker, J. R., and Chory, J. (2003). GUN4, a regulator of chlorophyll synthesis and intracellular signaling. Science 299, 902-906. doi: $10.1126 /$ science. 1079978

Larkindale, J., Hall, J. D., Knight, M. R., and Vierling, E. (2005). Heat stress phenotypes of Arabidopsis mutants implicate multiple signaling pathways in the acquisition of thermotolerance. Plant Physiol. 138, 882-897. doi: 10.1104/ pp.105.062257

Larkindale, J., and Knight, M. R. (2002). Protection against heat stress induced oxidative damage in Arabidopsis involves calcium, abscisic acid, ethylene, and salicylic acid. Plant Physiol. 128, 682-695. doi: 10.1104/pp.010320

Laude, A. J., and Prior, I. A. (2004). Plasma membrane microdomains: organization, function and trafficking. Mol. Membr. Biol. 21, 193-205. doi: 10.1080/09687680410001700517

Lee, B. H., Lee, H., Xiong, L., and Zhu, J. K. (2002). A mitochondrial complex I defect impairs cold-regulated nuclear gene expression. Plant Cell 14, 12351251. doi: $10.1105 /$ tpc.010433
Lenoir, G., Williamson, P., and Holthuis, J. C. (2007). On the origin of lipid asymmetry: the flip side of ion transport. Curr. Opin. Chem. Biol. 11, 654-661. doi: 10.1016/j.cbpa.2007.09.008

León, P., Gregorio, J., and Cordoba, E. (2013). ABI4 and its role in chloroplast retrograde communication. Front. Plant Sci. 3:304. doi: 10.3389/fpls.2012. 00304

Levitt, J. (ed.) (1980). "Responses of plants to environmental stress," in Chilling, Freezing, and High Temperature Stresses, (New York, NY: Academic Press).

Lherminier, J., Elmayan, T., Fromentin, J., Elaraqui, K. T., Vesa, S., Morel, J., et al. (2009). NADPH oxidase-mediated reactive oxygen species production: subcellular localization and reassessment of its role in plant defense. Mol. Plant Microbe Interact. 22, 868-881. doi: 10.1094/MPMI-22-7-0868

Li, B., Liu, H. T., Sun, D. Y., and Zhou, R. G. (2004). Ca2 ${ }^{+}$and calmodulin modulate DNA-binding activity of maize heat shock transcription factor in vitro. Plant Cell Physiol. 45, 627-634. doi: 10.1093/pcp/pch074

Li, S., Zhou, X., Chen, L., Huang, W., and Yu, D. (2010). Functional characterization of Arabidopsis thaliana WRKY39 in heat stress. Mol. Cells 29, 475-483. doi: 10.1007/s10059-010-0059-2

Li, W., Zhang, C., Lu, Q., Wen, X., and Lu, C. (2011). The combined effect of salt stress and heat shock on proteome profiling in Suaeda salsa. J. Plant Physiol. 168, 1743-1752. doi: 10.1016/j.jplph.2011.03.018

Lillemeier, B. F., Pfeiffer, J. R., Surviladze, Z., Wilson, B. S., and Davis, M. M. (2006). Plasma membrane-associated proteins are clustered into islands attached to the cytoskeleton. Proc. Natl. Acad. Sci. U.S.A. 103, 18992-18997. doi: 10.1073/pnas. 0609009103

Lingwood, D., and Simons, K. (2010). Lipid rafts as a membrane organizing principle. Science 327, 46-50. doi: 10.1126/science.1174621

Liu, C., Willmund, F., Golecki, J. R., Cacace, S., Hess, B., Markert, C., et al. (2007a). The chloroplast HSP70B-CDJ2-CGE1 chaperones catalyse assembly and disassembly of VIPP1 oligomers in Chlamydomonas. Plant J. 50, 265-277. doi: 10.1111/j.1365-313X.2007.03047.x

Liu, H. T., Li, G. L., Chang, H., Sun, D. Y., Zhou, R. G., and Li, B. (2007b). Calmodulin-binding protein phosphatase PP7 is involved in thermotolerance in Arabidopsis. Plant Cell Environ. 30, 156-164. doi: 10.1111/j.1365-3040.2006. 01613.x

Liu, H. C., and Charng, Y. Y. (2013). Common and distinct functions of Arabidopsis class A1 and A2 heat shock factors in diverse abiotic stress responses and development. Plant Physiol. 163, 276-290. doi: 10.1104/pp.113.221168

Liu, H. C., Liao, H. T., and Charng, Y. Y. (2011). The role of class A1 heat shock factors (HSFA1s) in response to heat and other stresses in Arabidopsis. Plant Cell Environ. 34, 738-751. doi: 10.1111/j.1365-3040.2011.02278.x

Liu, H. T., Gao, F., Cui, S. J., Han, J. L., Sun, D. Y., and Zhou, R. G. (2006). Primary evidence for involvement of IP3 in heat-shock signal transduction in Arabidopsis. Cell Res. 16, 394-400. doi: 10.1038/sj.cr.7310051

Liu, H. T., Gao, F., Li, G. L., Han, J. L., Liu, D. L., Sun, D. Y., et al. (2008). The calmodulin-binding protein kinase 3 is part of heat-shock signal transduction in Arabidopsis thaliana. Plant J. 55, 760-773. doi: 10.1111/j.1365-313X.2008. 03544.x

Liu, J. X., and Howell, S. H. (2016). Managing the protein folding demands in the endoplasmic reticulum of plants. New Phytol. 211, 418-428. doi: 10.1111/nph. 13915

Liu, Y., and He, C. (2016). Regulation of plant reactive oxygen species (ROS) in stress responses: learning from AtRBOHD. Plant Cell Rep. 35, 995-1007. doi: 10.1007/s00299-016-1950-x

Lv, Y., Shao, G., Qiu, J., Jiao, G., Sheng, Z., Xie, L., et al. (2017). White leaf and panicle 2, encoding a PEP-associated protein, is required for chloroplast biogenesis under heat stress in rice. J. Exp. Bot. 68, 5147-5160. doi: 10.1093/ jxb/erx332

Malinsky, J., Opekarová, M., Grossmann, G., and Tanner, W. (2013). Membrane microdomains, rafts, and detergent-resistant membranes in plants and fungi. Annu. Rev. Plant Biol. 64, 501-529. doi: 10.1146/annurev-arplant-050312120103

Marla, S. R., Shiva, S., Welti, R., Liu, S., Burke, J. J., and Morris, G. P. (2017). Comparative transcriptome and lipidome analyses reveal molecular chilling responses in chilling-tolerant sorghums. Plant Genome 10, 1-16. doi: 10.3835/ plantgenome2017.03.0025

Martinière, A., Lavagi, I., Nageswaran, G., Rolfe, D. J., Maneta-Peyret, L., Luu, D. T., et al. (2012). Cell wall constrains lateral diffusion of plant plasma-membrane 
proteins. Proc. Natl. Acad. Sci. U.S.A. 109, 12805-12810. doi: 10.1073/pnas. 1202040109

Maruyama, K., Takeda, M., Kidokoro, S., Yamada, K., Sakuma, Y., Urano, K., et al. (2009). Metabolic pathways involved in cold acclimation identified by integrated analysis of metabolites and transcripts regulated by DREB1A and DREB2A. Plant Physiol. 150, 1972-1980. doi: 10.1104/pp.109.135327

Matsuda, O., Sakamoto, H., Hashimoto, T., and Iba, K. (2005). A temperature sensitive mechanism that regulates post-translational stability of a plastidial omega-3 fatty acid desaturase (FAD8) in Arabidopsis leaf tissues. J. Biol. Chem. 280, 3597-3604. doi: 10.1074/jbc.M407226200

McClung, C. R., and Davis, S. J. (2010). Ambient thermometers in plants: from physiological outputs towards mechanisms of thermal sensing. Curr. Biol. 20, R1086-R1092. doi: 10.1016/j.cub.2010.10.035

McDowell, S. C., López-Marqués, R. L., Cohen, T., Brown, E., Rosenberg, A., Palmgren, M. G., et al. (2015). Loss of the Arabidopsis thaliana P4-ATPases ALA6 and ALA7 impairs pollen fitness and alters the pollen tube plasma membrane. Front. Plant Sci. 6:197. doi: 10.3389/fpls.2015.00197

McDowell, S. C., López-Marqués, R. L., Poulsen, L. R., Palmgren, M. G., and Harper, J. F. (2013). Loss of the Arabidopsis thaliana P4-ATPase ALA3 reduces adaptability to temperature stresses and impairs vegetative, pollen, and ovule development. PLoS One 8:e62577. doi: 10.1371/journal.pone.0062577

Meehl, G. A., and Tebaldi, C. (2004). More intense, more frequent, and longer lasting heat waves in the 21st century. Science 305, 994-997. doi: 10.1126/ science. 1098704

Merchant, S. S., Allen, M. D., Kropat, J., Moseley, J. L., Long, J. C., Tottey, S., et al. (2006). Between a rock and a hard place: trace element nutrition in Chlamydomonas. Biochim. Biophys. Acta 1763, 578-594. doi: 10.1016/j.bbamcr. 2006.04.007

Miller, G., and Mittler, R. (2006). Could heat shock transcription factors function as hydrogen peroxide sensors in plants? Ann. Bot. 98, 279-288. doi: 10.1093/ $\mathrm{aob} / \mathrm{mcl} 107$

Miller, G., Schlauch, K., Tam, R., Cortes, D., Torres, M. A., Shulaev, V., et al. (2009). The plant NADPH oxidase RBOHD mediates rapid systemic signaling in response to diverse stimuli. Sci. Signal. 2:ra45. doi: 10.1126/scisignal.200 0448

Miquel, M., James, D. Jr., Dooner, H., and Browse, J. (1993). Arabidopsis requires polyunsaturated lipids for low-temperature survival. Proc. Natl. Acad. Sci. U.S.A. 90, 6208-6212. doi: 10.1073/pnas.90.13.6208

Mishkind, M., Vermeer, J. E., Darwish, E., and Munnik, T. (2009). Heat stress activates phospholipase D and triggers PIP accumulation at the plasma membrane and nucleus. Plant J. 60, 10-21. doi: 10.1111/j.1365-313X.2009. 03933.x

Mittler, R., Finka, A., and Goloubinoff, P. (2012). How do plants feel the heat? Trends Biochem. Sci. 37, 118-125. doi: 10.1016/j.tibs.2011.11.007

Mittler, R., Vanderauwera, S., Gollery, M., and Van Breusegem, F. (2004). Reactive oxygen gene network of plants. Trends Plant Sci. 9, 490-498. doi: 10.1016/j. tplants.2004.08.009

Miura, K., and Furumoto, T. (2013). Cold signaling and cold response in plants. Int. J. Mol. Sci. 14, 5312-5337. doi: 10.3390/ijms14035312

Mochizuki, N., Brusslan, J. A., Larkin, R., Nagatani, A., and Chory, J. (2001). Arabidopsis genomes uncoupled 5 (GUN5) mutant reveals the involvement of Mg-chelatase $\mathrm{H}$ subunit in plastid-to-nucleus signal transduction. Proc. Natl. Acad. Sci. U.S.A. 98, 2053-2058. doi: 10.1073/pnas.98.4.2053

Møller, I. M., and Kristensen, B. K. (2004). Protein oxidation in plant mitochondria as a stress indicator. Photochem. Photobiol. Sci. 3, 730-735. doi: 10.1039/ B315561G

Mullarkey, M., and Jones, P. (2000). Isolation and analysis of thermotolerant mutant of wheat. J. Exp. Bot. 51, 139-146. doi: 10.1093/jexbot/51.342.139

Nathan, D. F., Vos, M. H., and Lindquist, S. (1997). In vivo functions of the Saccharomyces cerevisiae Hsp 90 chaperone. Proc. Natl. Acad. Sci. U.S.A. 94, 12949-12956. doi: 10.1073/pnas.94.24.12949

Nievola, C. C., Carvalho, C. P., Carvalho, V., and Rodrigues, E. (2017). Rapid responses of plants to temperature changes. Temperature 4, 371-405. doi: 10.1080/23328940.2017.1377812

Niu, Y., Qian, D., Liu, B., Ma, J., Wan, D., Wang, X., et al. (2017). ALA6, a P4-type ATPase, is involved in heat stress responses in Arabidopsis thaliana. Front. Plant Sci. 8:1732. doi: 10.3389/fpls.2017.01732
Ohnishi, N., Zhang, L., and Sakamoto, W. (2018). VIPP1 involved in chloroplast membrane integrity has GTPase activity in vitro. Plant Physiol. 177, 328-338. doi: $10.1104 /$ pp. 18.00145

O’Quin, J. B., Bourassa, L., Zhang, D., Shockey, J. M., Gidda, S. K., Fosnot, S., et al. (2010). Temperature-sensitive post-translational regulation of plant omega3 fatty-acid desaturases is mediated by the endoplasmic reticulum-associated degradation pathway. J. Biol. Chem. 285, 21781-21796. doi: 10.1074/jbc.M110. 135236

Ortiz-Masia, D., Perez-Amador, M. A., Carbonell, P., Aniento, F., Carbonell, J., and Marcote, M. J. (2008). Characterization of PsMPK2, the first C1 subgroup MAP kinase from pea (Pisum sativum L.). Planta 227, 1333-1342. doi: 10.1007/ s00425-008-0705-5

Pan, R. H., Jones, A. D., and Hu, J. P. (2014). Cardiolipin-mediated mitochondrial dynamics and stress response in Arabidopsis. Plant Cell 26, 391-409. doi: 10. 1105/tpc.113.121095

Paradies, G., Ruggiero, F. M., Petrosillo, G., and Quagliariello, E. (1998). Peroxidative damage to cardiac mitochondria: cytochrome oxidase and cardiolipin alterations. FEBS Lett. 424, 155-158. doi: 10.1016/S0014-5793(98) 00161-6

Park, S., Lee, C. M., Doherty, C. J., Gilmour, S. J., Kim, Y., and Thomashow, M. F. (2015). Regulation of the Arabidopsis CBF regulon by a complex low-temperature regulatory network. Plant J. 82, 193-207. doi: 10.1111/tpj. 12796

Penfield, S. (2008). Temperature perception and signal transduction in plants. New Phytol. 179, 615-628. doi: 10.1111/j.1469-8137.2008.02478.x

Pitzschke, A., and Hirt, H. (2009). Disentangling the complexity of mitogenactivated protein kinases and reactive oxygen species signaling. Plant Physiol. 149, 606-615. doi: 10.1104/pp.108.131557

Plieth, C. (1999). Temperature sensing by plants: calcium-permeable channels as primary sensors - a model. J. Membr. Biol. 172, 121-127. doi: 10.1007/ s002329900590

Plieth, C., Hansen, U. P., Knight, H., and Knight, M. R. (1999). Temperature sensing by plants: the primary characteristics of signal perception and calcium response. Plant J. 18, 491-497. doi: 10.1046/j.1365-313x.1999.00471.x

Pomorski, T. G., and Menon, A. K. (2016). Lipid somersaults: uncovering the mechanisms of protein-mediated lipid flipping. Prog. Lipid Res. 64, 69-84. doi: 10.1016/j.plipres.2016.08.003

Pospíšil, P., Haumann, M., Dittmer, J., and Dau, H. (2003). Stepwise transition of the tetra-manganese complex of photosystem II to a binuclear Mn2( $\mu-\mathrm{O}) 2$ complex in response to a temperature jump: a time-resolved structural investigation employing X-Ray absorption spectroscopy. Biophys. J. 84, 1370-1386. doi: 10.1016/S0006-3495(03)74952-2

Pospíšil, P., and Prasad, A. (2014). Formation of singlet oxygen and protection against its oxidative damage in photosystem II under abiotic stress. J. Photochem. Photobiol. B Biol. 137, 39-48. doi: 10.1016/j.jphotobiol.2014. 04.025

Pospíšil, P., Šnyrychová, I., and Nauš, J. (2007). Dark production of reactive oxygen species in photosystem II membrane particles at elevated temperature: EPR spin-trapping study. Biochim. Biophys. Acta 1767, 854-859. doi: 10.1016/j. bbabio.2007.02.011

Pospíšil, P., and Tyystjärvi, E. (1999). Molecular mechanism of high-temperatureinduced inhibition of acceptor side of photosystem II. Photosynth. Res. 62, 55-66. doi: 10.1023/A:1006369009170

Pospíšil, P., and Yamamoto, Y. (2017). Damage to photosystem II by lipid peroxidation products. Biochim. Biophys. Acta 1861, 457-466. doi: 10.1016/j. bbagen.2016.10.005

Prasad, A., Ferretti, U., Sedlářová, M., and Pospíšil, P. (2016). Singlet oxygen production in Chlamydomonas reinhardtii under heat stress. Sci. Rep. 6:20094. doi: 10.1038/srep20094

Pröschold, T., Harris, E. H., and Coleman, A. W. (2005). Portrait of a species: Chlamydomonas reinhardtii. Genetics 170, 1601-1610. doi: 10.1534/genetics. 105.044503

Pyatrikas, D. V., Rikhvanov, E. G., Fedoseeva, I. V., Varakina, N. N., Rusaleva, T. M., Tauson, E. L., et al. (2014). Mitochondrial retrograde regulation of HSP101 expression in Arabidopsis thaliana under heat stress and amiodarone action. Russ. J. Plant Physiol. 61, 80-89. doi: 10.1134/S102144371401 0117 
Ramot, D., Macinnis, B. L., and Goodman, M. B. (2008). Bidirectional temperaturesensing by a single thermosensory neuron in C. elegans. Nat. Neurosci. 11, 908-915. doi: 10.1038/nn.2157

Ren, H., Gao, K., Liu, Y., Sun, D., and Zheng, S. (2017). The role of AtPLC3 and AtPLC9 in thermotolerance in Arabidopsis. Plant Signal. Behav. 12:e1162368. doi: $10.1080 / 15592324.2016 .1162368$

Rhoads, D. M., and Subbaiah, C. C. (2007). Mitochondrial retrograde regulation in plants. Mitochondrion 7, 177-194. doi: 10.1016/j.mito.2007.01.002

Rhoads, D. M., Umbach, A. L., Subbaiah, C. C., and Siedow, J. N. (2006). Mitochondrial reactive oxygen species. Contribution to oxidative stress and interorganellar signaling. Plant Physiol. 141, 357-366. doi: 10.1104/pp.106. 079129

Rikhvanov, E. G., Fedoseeva, I. V., Pyatrikas, D. V., Borovskii, G. B., and Voinikov, V. K. (2014). Role of mitochondria in the operation of calcium signaling system in heat-stressed plants. Russ. J. Plant Physiol. 61, 141-153. doi: 10.1134/ S1021443714020125

Ritossa, F. (1962). A new puffing pattern induced by temperature shock and DNP in Drosophila. Experientia 18, 571-573. doi: 10.1007/BF02172188

Ron, D., and Walter, P. (2007). Signal integration in the endoplasmic reticulum unfolded protein response. Nat. Rev. Mol. Cell Biol. 8, 519-529. doi: 10.1038/ nrm2199

Ruelland, E., Cantrel, C., Gawer, M., Kader, J. C., and Zachowski, A. (2002). Activation of phospholipases $\mathrm{C}$ and $\mathrm{D}$ is an early response to a cold exposure in Arabidopsis suspension cells. Plant Physiol. 130, 999-1007. doi: 10.1104/pp. 006080

Ruelland, E., and Zachowski, A. (2010). How plants sense temperature. Environ. Exp. Bot. 69, 225-232. doi: 10.1016/j.envexpbot.2010.05.011

Rutgers, M., and Schroda, M. (2013). A role of VIPP1 as a dynamic structure within thylakoid centers as sites of photosystem biogenesis? Plant Signal. Behav. 8:e27037. doi: 10.4161/psb.27037

Saidi, Y., Finka, A., Chakhporanian, M., Zryd, J. P., Schaefer, D. G., and Goloubinoff, P. (2005). Controlled expression of recombinant proteins in Physcomitrella patens by a conditional heat-shock promoter: a tool for plant research and biotechnology. Plant Mol. Biol. 59, 697-711. doi: 10.1007/s11103005-0889-Z

Saidi, Y., Finka, A., and Goloubinoff, P. (2011). Heat perception and signalling in plants: a tortuous path to thermotolerance. New Phytol. 190, 556-565. doi: $10.1111 / j .1469-8137.2010 .03571 . x$

Saidi, Y., Finka, A., Muriset, M., Bromberg, Z., Weiss, Y. G., Maathuis, F. J., et al. (2009). The heat shock response in moss plants is regulated by specific calciumpermeable channels in the plasma membrane. Plant Cell 21, 2829-2843. doi: $10.1105 /$ tpc. 108.065318

Saidi, Y., Peter, P., Finka, A., Cicekli, C., Vigh, L., and Goloubinoff, P. (2010). Membrane lipid composition affects plant heat sensing and modulates $\mathrm{Ca}_{2}{ }^{+}$. dependent heat shock response. Plant Signal. Behav. 5, 1530-1533. doi: 10.4161/ psb.5.12.13163

Sánchez-García, A., Mancha, M., Heinz, E., and Martínez-Rivas, J. M. (2004). Differential temperature regulation of three sunflower microsomal oleate desaturase (FAD2) isoforms overexpressed in Saccharomyces cerevisiae. Eur. J. Lipid Sci. Technol. 106, 583-590. doi: 10.1002/ejlt.200401005

Scharf, K. D., Berberich, T., Ebersberger, I., and Nover, L. (2012). The plant heat stress transcription factor (Hsf) family: structure, function and evolution. Biochim. Biophys. Acta 1819, 104-119. doi: 10.1016/j.bbagrm.2011. 10.002

Schramm, F., Larkindale, J., Kiehlmann, E., Ganguli, A., Englich, G., Vierling, E., et al. (2008). A cascade of transcription factor DREB2A and heat stress transcription factor HsfA3 regulates the heat stress response of Arabidopsis. Plant J. 53, 264-274. doi: 10.1111/j.1365-313X.2007.03334.x

Schroda, M., Hemme, D., and Mühlhaus, T. (2015). The Chlamydomonas heat stress response. Plant J. 82, 466-480. doi: 10.1111/tpj.12816

Schroda, M., Vallon, O., Wollman, F. A., and Beck, C. F. (1999). A chloroplasttargeted heat shock protein 70 (HSP70) contributes to the photoprotection and repair of photosystem II during and after photoinhibition. Plant Cell 11, 1165-1178. doi: 10.1105/tpc.11.6.1165

Segawa, K., Kurata, S., Yanagihashi, Y., Brummelkamp, T. R., Matsuda, F., and Nagata, S. (2014). Caspase-mediated cleavage of phospholipid flippase for apoptotic phosphatidylserine exposure. Science 344, 1164-1168. doi: 10.1126/ science. 1252809
Segawa, K., Suzuki, J., and Nagata, S. (2011). Constitutive exposure of phosphatidylserine on viable cells. Proc. Natl. Acad. Sci. U.S.A. 108, 1924619251. doi: 10.1073/pnas.1114799108

Shah, M., Patel, K., Fried, V. A., and Sehgal, P. B. (2002). Interactions of STAT3 with caveolin-1 and heat shock protein 90 in plasma membrane raft and cytosolic complexes. Preservation of cytokine signaling during fever. J. Biol. Chem. 277, 45662-45669. doi: 10.1074/jbc.M205935200

Shakeel, S., Haq, N. U., Heckathorn, S. A., Hamilton, E. W., and Luthe, D. S. (2011). Ecotypic variation in chloroplast small heat-shock proteins and related thermotolerance in Chenopodium album. Plant Physiol. Biochem. 49, 898-908. doi: 10.1016/j.plaphy.2011.05.002

Shank, K. J., Su, P., Brglez, I., Boss, W. F., Dewey, R. E., and Boston, R. S. (2001). Induction of lipid metabolic enzymes during the endoplasmic reticulum stress response in plants. Plant Physiol. 126, 267-277. doi: 10.1104/pp.126.1.267

Sharkey, T. D. (2000). Some like it hot. Science 287, 435-437. doi: 10.1126/science. 287.5452.435

Shinozaki, K., Uemura, M., Bailey-Serres, J., Bray, E. A., and Weretilnyk, E. (2015). "Responses to abiotic stress," in Biochemistry and Molecular Biology of Plants, eds B. B. Buchanan, W. Gruissem, K. Vickers, and R. L. Jones (Hoboken, NJ: John Wiley \& Sons Press).

Siddhanta, A., and Shields, D. (1998). Secretory vesicle budding from the transGolgi network is mediated by phosphatidic acid levels. J. Biol. Chem. 273, 17995-17998. doi: 10.1074/jbc.273.29.17995

Simons, K., and Ikonen, E. (1997). Functional rafts in cell membranes. Nature 387, 569-572. doi: 10.1038/42408

Simons, K., and Toomre, D. (2000). Lipid rafts and signal transduction. Nat. Rev. Mol. Cell Biol. 1, 31-39. doi: 10.1038/35036052

Singer, S. D., Zou, J., and Weselake, R. J. (2016). Abiotic factors influence plant storage lipid accumulation and composition. Plant Sci. 243, 1-9. doi: 10.1016/j. plantsci.2015.11.003

Singer, S. J., and Nicolson, G. L. (1972). The fluid mosaic model of the structure of cell membranes. Science 175, 720-731. doi: 10.1126/science.175.4023.720

Smart, C. C., and Fleming, A. J. (1996). Hormonal and environmental regulation of a plant PDR5-like ABC transporter. J. Biol. Chem. 271, 19351-19357. doi: $10.1074 /$ jbc.271.32.19351

Smékalová, V., Doskočilová, A., Komis, G., and Samaj, J. (2014). Crosstalk between secondary messengers, hormones and MAPK modules during abiotic stress signalling in plants. Biotechnol. Adv. 32, 2-11. doi: 10.1016/j.biotechadv.2013. 07.009

Somerville, C., Browse, J., Jaworski, J. G., and Ohlrogge, J. B. (2000). "Lipids," in Biochemistry and Molecular Biology of Plants, eds B. B. Buchanan, W. Gruissem, and R. L. Jones (Rockville, MD: American Society of Plant Biologists Press), 456-527.

Song, W., Maeda, H., and DellaPenna, D. (2010). Mutations of the ER to plastid lipid transporters TGD1, 2, 3 and 4 and the ER oleate desaturase FAD2 suppress the low temperature-induced phenotype of Arabidopsis tocopherol-deficient mutant vte2. Plant J. 62, 1004-1018. doi: 10.1111/j.1365-313X.2010.04212.x

Stout, R. G., Summers, M. L., Kerstetter, T., and McDermott, T. R. (1997). Heatand acid-tolerance of a grass commonly found in geothermal areas within Yellowstone National Park. Plant Sci. 130, 1-9. doi: 10.1016/S0168-9452(97) 00205-7

Strand, A., Asami, T., Alonso, J., Ecker, J. R., and Chory, J. (2003). Chloroplast to nucleus communication triggered by accumulation of Mg-protoporphyrin IX. Nature 421, 79-83. doi: 10.1038/nature01204

Sun, A. Z., and Guo, F. Q. (2016). Chloroplast retrograde regulation of heat stress responses in plants. Front. Plant Sci. 7:398. doi: 10.3389/fpls.2016.00398

Suri, S. S., and Dhindsa, R. S. (2008). A heat-activated MAP kinase (HAMK) as a mediator of heat shock response in tobacco cells. Plant Cell Environ. 31, 218-226. doi: 10.1111/j.1365-3040.2007.01754.x

Susek, R. E., Ausubel, F. M., and Chory, J. (1993). Signal-transduction mutants of Arabidopsis uncouple nuclear $\mathrm{CAB}$ and RBCS gene-expression from chloroplast development. Cell 74, 787-799. doi: 10.1016/0092-8674(93)90459-4

Suzuki, N., Koussevitzky, S., Mittler, R., and Miller, G. (2012). ROS and redox signalling in the response of plants to abiotic stress. Plant Cell Environ. 35, 259-270. doi: 10.1111/j.1365-3040.2011.02336.x

Suzuki, N., Sejima, H., Tam, R., Schlauch, K., and Mittler, R. (2011). Identification of the MBF1 heat-response regulon of Arabidopsis thaliana. Plant J. 66, 844-851. doi: 10.1111/j.1365-313X.2011.04550.x 
Sweetlove, L. J., Heazlewood, J. L., Herald, V., Holtzapffel, R., Day, D. A., Leaver, C. J., et al. (2002). The impact of oxidative stress on Arabidopsis mitochondria. Plant J. 32, 891-904. doi: 10.1046/j.1365-313X.2002.01474.X

Tang, G. Q., Novitzky, W. P., Carol Griffin, H., Huber, S. C., and Dewey, R. E. (2005). Oleate desaturase enzymes of soybean: evidence of regulation through differential stability and phosphorylation. Plant J. 44, 433-446. doi: 10.1111/j. 1365-313X.2005.02535.x

Tang, T., Liu, P., Zheng, G., and Li, W. (2016). Two phases of response to longterm moderate heat: variation in thermotolerance between Arabidopsis thaliana and its relative Arabis paniculata. Phytochemistry 122, 81-90. doi: 10.1016/j. phytochem.2016.01.003

Tanner, W., Malinsky, J., and Opekarová, M. (2011). In plant and animal cells, detergent-resistant membranes do not define functional membrane rafts. Plant Cell 23, 1191-1193. doi: 10.1105/tpc.111.086249

Taylor, S. W., Fahy, E., Murray, J., Capaldi, R. A., and Ghosh, S. S. (2003). Oxidative post-translational modification of tryptophan residues in cardiac mitochondrial proteins. J. Biol. Chem. 278, 19587-19590. doi: 10.1074/jbc.C300 135200

Testerink, C., and Munnik, T. (2005). Phosphatidic acid: a multifunctional stress signalling lipid in plants. Trends Plant Sci. 10, 368-375. doi: 10.1016/j.tplants. 2005.06.002

Thibault, G., Shui, G., Kim, W., McAlister, G. C., Ismail, N., and Gygi, S. P. (2012). The membrane stress response buffers lethal effects of lipid disequilibrium by reprogramming the protein homeostasis network. Mol. Cell 48, 16-27. doi: 10.1016/j.molcel.2012.08.016

Thompson, T. E., and Tillack, T. W. (1985). Organization of glycosphingolipids in bilayers and plasma membranes of mammalian cells. Annu. Rev. Biophys. Biophys. Chem. 14, 361-386. doi: 10.1146/annurev.bb.14.060185.002045

Triantaphylides, C., and Havaux, M. (2009). Singlet oxygen in plants: production, detoxification and signaling. Trends Plant Sci. 14, 219-228. doi: 10.1016/j. tplants.2009.01.008

Triantaphylides, C., Krischke, M., Hoeberichts, F. A., Ksas, B., Gresser, G., Havaux, M., et al. (2008). Singlet oxygen is the major reactive oxygen species involved in photooxidative damage to plants. Plant Physiol. 148, 960-968. doi: $10.1104 /$ pp.108.125690

Trösch, R., Mühlhaus, T., Schroda, M., and Willmund, F. (2015). ATP-dependent molecular chaperones in plastids - More complex than expected. Biochim. Biophys. Acta 1847, 872-888. doi: 10.1016/j.bbabio.2015.01.002

van Meer, G., Voelker, D. R., and Feigenson, G. W. (2008). Membrane lipids: where they are and how they behave. Nat. Rev. Mol. Cell Biol. 9, 112-124. doi: $10.1038 / \mathrm{nrm} 2330$

Vega, V. L., and De Maio, A. (2005). Increase in phagocytosis after geldanamycin treatment or heat shock: role of heat shock proteins. J. Immunol. 175, 5280-5287. doi: 10.4049/jimmunol.175.8.5280

Vereb, G., Szollosi, J., Matko, J., Nagy, P., Farkas, T., Vigh, L., et al. (2003). Dynamic, yet structured: the cell membrane three decades after the SingerNicolson model. Proc. Natl. Acad. Sci. U.S.A. 100, 8053-8058. doi: 10.1073/pnas. 1332550100

Vigh, L., Escribá, P. V., Sonnleitner, A., Sonnleitner, M., Piotto, S., Maresca, B., et al. (2005). The significance of lipid composition for membrane activity: new concepts and ways of assessing function. Prog. Lipid Res. 44, 303-344. doi: 10.1016/j.plipres.2005.08.001

Vigh, L., Nakamoto, H., Landry, J., Gomez-Munoz, A., Harwood, J. L., and Horvath, I. (2007a). Membrane regulation of the stress response from prokaryotic models to mammalian cells. Ann. N. Y. Acad. Sci. 1113, 40-51. doi: 10.1196/annals.1391.027

Vigh, L., Török, Z. S., Balogh, G., Glatz, A., Piotto, S., and Horváth, I. (2007b). "Membrane-regulated stress response," in A Theoretical and Practical Approach in Molecular Aspects of the Stress Response: Chaperones, Membranes and Networks, eds P. Csermely and L. Vigh (Austin, TX: Landes Bioscience), 114-142. doi: 10.1007/978-0-387-39975-1_11

von Koskull-Döring, P., Scharf, K. D., and Nover, L. (2007). The diversity of plant heat stress transcription factors. Trends Plant Sci. 12, 452-457. doi: 10.1016/j. tplants.2007.08.014

Voss, B., Meinecke, L., Kurz, T., Al-Babili, S., Beck, C. F., and Hess, W. R. (2011). Hemin and magnesium-protoporphyrin IX induce global changes in gene expression in Chlamydomonas reinhardtii. Plant Physiol. 155, 892-905. doi: $10.1104 /$ pp.110.158683
Wallis, J. G., and Browse, J. (2002). Mutants of Arabidopsis reveal many roles for membrane lipids. Prog. Lipid Res. 41, 254-278. doi: 10.1016/S0163-7827(01) 00027-3

Walter, P., and Ron, D. (2011). The unfolded protein response: from stress pathway to homeostatic regulation. Science 334, 1081-1086. doi: 10.1126/ science. 1209038

Wang, G. F., Li, W. Q., Li, W. Y., Wu, G. L., Zhou, C. Y., and Chen, K. M. (2013). Characterization of rice NADPH oxidase genes and their expression under various environmental conditions. Int. J. Mol. Sci. 14, 9440-9458. doi: 10.3390/ijms14059440

Wang, L., Xue, Y., Xing, J., Song, K., and Lin, J. (2018). Exploring the spatiotemporal organization of membrane proteins in living plant cells. Annu. Rev. Plant Biol. 69, 525-551. doi: 10.1146/annurev-arplant-042817040233

Ward, J. M., Maser, P., and Schroeder, J. I. (2009). Plant ion channels: gene families, physiology, and functional genomics analyses. Annu. Rev. Physiol. 71, 59-82. doi: 10.1146/annurev.physiol.010908.163204

Weis, E., and Berry, J. A. (1988). Plants and high temperature stress. Symp. Soc. Exp. Biol. 42, 329-346.

Wood, R., and Harlow, R. D. (1969). Structural analyses of rat liver phosphoglycerides. Arch. Biochem. Biophys. 135, 272-281. doi: 10.1016/00039861(69)90540-2

Woodson, J. D., and Chory, J. (2008). Coordination of gene expression between organellar and nuclear genomes. Nat. Rev. Genet. 9, 383-395. doi: 10.1038/ $\operatorname{nrg} 2348$

Wu, H. C., and Jinn, T. L. (2010). Ethylesterase activity and cytosolic Ca2 ${ }^{+}$ oscillation are crucial for plant thermotolerance. Plant Signal. Behav. 5, 12521256. doi: $10.4161 /$ psb.5.10.12607

Wu, H. C., and Jinn, T. L. (2012). Oscillation regulation of $\mathrm{Ca}^{+} /$calmodulin and heat-stress related genes in response to heat stress in rice (Oryza sativa L.). Plant Signal Behav. 7, 1056-1057. doi: 10.4161/psb.21124

Wu, J., Lightner, J., Warwick, N., and Browse, J. (1997). Low-temperature damage and subsequent recovery of fabl mutant Arabidopsis exposed to 2 degrees C. Plant Physiol. 113, 347-356. doi: 10.1104/pp.113.2.347

Wu, J., Zhang, Y., Yin, L., Qu, J., and Lu, J. (2014). Linkage of cold acclimation and disease resistance through plant-pathogen interaction pathway in Vitis amurensis grapevine. Funct. Integr. Genomics 14, 741-755. doi: 10.1007/s10142014-0392-1

Xing, Y., Jia, W., and Zhang, J. (2008). AtMKK1 mediates ABA induced CAT1 expression and $\mathrm{H} 2 \mathrm{O} 2$ production via AtMPK6-coupled signaling in Arabidopsis. Plant J. 54, 440-451. doi: 10.1111/j.1365-313X.2008. 03433.x

Xiong, F. S., Mueller, E. C., and Day, T. A. (2000). Photosynthetic and respiratory acclimation and growth response of Antarctic vascular plants to contrasting temperature regimes. Am. J. Bot. 87, 700-710. doi: 10.2307/ 2656856

Yabuuchi, H., and O’Brien, J. S. (1968). Positional distribution of fatty acids in glycerophosphatides of bovine gray matter. J. Lipid Res. 9, 65-67.

Yadav, D. K., and Pospišil, P. (2012). Role of chloride ion in hydroxyl radical production in photosystem II under heat stress: electron paramagnetic resonance spin-trapping study. J. Bioenerg. Biomembr. 44, 365-372. doi: 10. 1007/s10863-012-9433-4

Yamamoto, Y., Aminaka, R., Yoshioka, M., Khatoon, M., Komayama, K., Takenaka, D., et al. (2008). Quality control of photosystem II: impact of light and heat stresses. Photosynth. Res. 98, 589-608. doi: 10.1007/s11120-0089372-4

Yamamoto, Y., Kai, S., Ohnishi, A., Tsumura, N., Ishikawa, T., Hori, H., et al. (2014). Quality control of PSII: behavior of PSII in the highly crowded grana thylakoids under excessive light. Plant Cell Physiol. 55, 1206-1215. doi: 10.1093/ pcp/pcu043

Yamashita, A., Nijo, N., Pospísil, P., Morita, N., Takenaka, D., Aminaka, R., et al. (2008). Quality control of photosystem II: reactive oxygen species are responsible for the damage to photosystem II under moderate heat stress. J. Biol. Chem. 283, 28380-28391. doi: 10.1074/jbc.M710465200

Yamauchi, Y., Furutera, A., Seki, K., Toyoda, Y., Tanaka, K., and Sugimoto, Y. (2008). Malondialdehyde generated from peroxidized linolenic acid causes protein modification in heat-stressed plants. Plant Physiol. Biochem. 46, 786793. doi: 10.1016/j.plaphy.2008.04.018 
Yamauchi, Y., and Sugimoto, Y. (2010). Effect of protein modification by malondialdehyde on the interaction between the oxygen-evolving complex 33 $\mathrm{kDa}$ protein and photosystem II core proteins. Planta 231, 1077-1088. doi: 10.1007/s00425-010-1112-2

Yao, J., Liu, B., and Qin, F. (2011). Modular thermal sensors in temperature-gated transient receptor potential (TRP) channels. Proc. Natl. Acad. Sci. U.S.A. 108, 11109-11114. doi: 10.1073/pnas.1105196108

Yoshioka, M., Uchida, S., Mori, H., Komayama, K., Ohira, S., Morita, N., et al. (2006). Quality control of photosystem II. Cleavage of reaction center D1 protein in spinach thylakoids by $\mathrm{FtsH}$ protease under moderate heat stress. J. Biol. Chem. 281, 21660-21669. doi: 10.1074/jbc.M602 896200

Yu, C. Y., Nguyen, V. C., Chuang, L., and Kanehara, K. (2018). Membrane glycerolipid equilibrium under endoplasmic reticulum stress in Arabidopsis thaliana. Biochem. Biophys. Res. Commun. 500, 103-109. doi: 10.1016/j.bbrc. 2018.03.025

Yu, H. D., Yang, X. F., Chen, S. T., Wang, Y. T., Li, J. K., Shen, Q., et al. (2012). Downregulation of chloroplast RPS1 negatively modulates nuclear heatresponsive expression of HsfA2 and its target genes in Arabidopsis. PLoS Genet. 8:e1002669. doi: 10.1371/journal.pgen.1002669

Zhang, L., Kondo, H., Kamikubo, H., Kataoka, M., and Sakamoto, W. (2016). VIPP1 has a disordered C-terminal tail necessary for protecting photosynthetic membranes against stress. Plant Physiol. 171, 1983-1995. doi: 10.1104/pp.16. 00532

Zhang, M., Barg, R., Yin, M., Gueta-Dahan, Y., Leikin-Frenkel, A., Salts, Y., et al. (2005). Modulated fatty acid desaturation via overexpression of two distinct omega-3 desaturases differentially alters tolerance to various abiotic stresses in transgenic tobacco cells and plants. Plant J. 44, 361-371. doi: 10.1111/j.1365313X.2005.02536.X

Zhang, Z. W., Zhang, G. C., Zhu, F., Zhang, D. W., and Yuan, S. (2015). The roles of tetrapyrroles in plastid retrograde signaling and tolerance to environmental stresses. Planta 242, 1263-1276. doi: 10.1007/s00425-015-2384-3
Zheng, S. Z., Liu, Y. L., Li, B., Shang, Z. L., Zhou, R. G., and Sun, D. Y. (2012). Phosphoinositide-specific phospholipase C9 is involved in the thermotolerance of Arabidopsis. Plant J. 69, 689-700. doi: 10.1111/j.1365-313X.2011.04823.x

Zhong, L., Zhou, W., Wang, H., Ding, S., Lu, Q., Wen, X., et al. (2013). Chloroplast small heat shock protein HSP21 interacts with plastid nucleoid protein pTAC5 and is essential for chloroplast development in Arabidopsis under heat stress. Plant Cell 25, 2925-2943. doi: 10.1105/tpc.113.111229

Zhou, J., Xia, X. J., Zhou, Y. H., Shi, K., Chen, Z., and Yu, J. Q. (2014). RBOH1dependent $\mathrm{H} 2 \mathrm{O} 2$ production and subsequent activation of MPK1/2 play an important role in acclimation-induced cross-tolerance in tomato. J. Exp. Bot. 65, 595-607. doi: 10.1093/jxb/ert404

Zhu, J. K. (2016). Abiotic stress signaling and responses in plants. Cell 167, 313-324. doi: 10.1016/j.cell.2016.08.029

Zong, X. J., Li, D. P., Gu, L. K., Li, D. Q., Liu, L. X., and Hu, X. L. (2009). Abscisic acid and hydrogen peroxide induce a novel maize group C MAP kinase gene, $\mathrm{ZmMPK} 7$, which is responsible for the removal of reactive oxygen species. Planta 229, 485-495. doi: 10.1007/s00425-008-0848-4

Zrobek-Sokolnik, A. (2012). “Temperature stress and responses of plants," in Environmental Adaptations and Stress Tolerance of Plants in the Era of Climate Change, eds P. Ahmad and M. N. V. Prasad (New York, NY: Springer Press), 113-134. doi: 10.1007/978-1-4614-0815-4_5

Conflict of Interest Statement: The authors declare that the research was conducted in the absence of any commercial or financial relationships that could be construed as a potential conflict of interest.

Copyright (c) 2018 Niu and Xiang. This is an open-access article distributed under the terms of the Creative Commons Attribution License (CC BY). The use, distribution or reproduction in other forums is permitted, provided the original author(s) and the copyright owner(s) are credited and that the original publication in this journal is cited, in accordance with accepted academic practice. No use, distribution or reproduction is permitted which does not comply with these terms. 